\title{
Kurumsal İletişim Çerçevesinde Türkiye'de Pazarlama Odaklı Spor Sponsorluğu Üzerine Bir Analiz ${ }^{1}$
}

\author{
Nilüfer Fatma GÖKSU² ve Burcu ÖZCAN KEÇECI ${ }^{3}$
}

\section{$\ddot{O} z$}

Bir yanıyla iş odaklı ticari bir alan olan endüstrileşmiş spor olgusu kitleleri peşinden sürüklerken, diğer taraftan da hobi amaçlı yapısıyla boş zaman aktivitesi olarak kişilerin hayatlarında büyük bir yer teşkil etmektedir. Böyle geniş ve dinamik bir alanda hedef kitleye istenen mesajların ulaştıılması için iletişimin tüm olanaklarını kullanmak kaçınılmazdır. Bu nedenle sporcular, spor kulüpleri, ticari firmalar, tedarikçiler, antrenörler, vb. spor pazarı ile ilgili tüm oyuncuların arasında doğru bir iletişimin yönetilmesi gerekmektedir. Spor iletişimi çerçevesinde gerçekleşecek olan bu iletişimde pazarlama, halkla ilişkiler, reklam, promosyon, sponsorluk, vb. iletişim yöntemleri kullanılarak hem ekonomik hem de sosyal hayata artı değer katacak etkileşimler sağlanmaktadır. Yapılan tüm yatırımlar hem sponsor firmaya, hem ülkeye, hem sporcuya, hem de sponsor olunan spor dalına olumlu yönden katkı sağlamakta ve çift yönlü gelişime zemin hazırlamaktadır. Türk firmaları spor sponsorluğu alanında ciddi yatırımlar yapmakta, hem sporcu ve sporun gelişimi için faaliyet göstermekte hem de markalarını uluslararası platformlarda konumlandırmak adına dünyanın farklı bölgelerinde spor kulüplerine, sporculara, spor liglerine ve spor organizasyonlarına sponsor olmaktadırlar. Bu nedenle, bu çalışmada çeşitli sektörlerden firmaların tanıtım ve pazarlama bütçelerinin önemli bir bölümünü spor sponsorluğuna ayırdığ1 Türkiye'de konuyla ilgili bir betimsel analiz gerçekleştirilmiştir.

Anahtar Kelimeler: Spor İletişimi, Sponsorluk, Spor Sponsorluğu

\section{An Analysis on Marketing-oriented Sports Sponsorship in Turkey within the Framework of Corporate Communication}

\begin{abstract}
The industrialized sports phenomenon which is a business-oriented commercial field drags the masses after them; on the other hand, it has a great place in the lives of people as a leisure activity with its hobby purpose. In such a broad and dynamic area, it is inevitable to use all the possibilities of communication to deliver the desired messages to the target audience. For this reason, it is necessary to manage a correct communication between athletes, sports clubs, commercial companies, suppliers, coaches and all players related to the sports market. In this communication, which will take place within the framework of sports communication, interactions that will add value to both economic and social life are provided by using marketing, public relations, advertising, promotion, sponsorship and similar communication methods. All investments made contribute positively to the sponsor company, the country, the athlete and the sponsored sports branch, and lay the groundwork for bilateral development. Turkish companies make serious investments in the field of sports sponsorship, operate for the development of athletes and sports, and also sponsor sports clubs, sportsmen, sports leagues and sports organizations in different regions of the world in order to position their brands on international platforms. Therefore, in this study, a descriptive analysis has been conducted in Turkey, which devotes a significant portion of the companies' sponsorship of sports promotion and marketing budget from various sectors.
\end{abstract}

Key Words: Sports Communication, Sponsorship, Sports Sponsorship

\section{Atıf İçin / Please Cite As:}

Göksu, N. F. ve Özcan Keçeci, B. (2021). Kurumsal iletişim çerçevesinde Türkiye'de pazarlama odaklı spor sponsorluğu üzerine bir analiz. Manas Sosyal Araşttrmalar Dergisi, 10(2), 1225-1246.

Geliş Tarihi / Received Date: 14.01.2021

Kabul Tarihi / Accepted Date: 04.02.2021

\footnotetext{
${ }^{1}$ Bu makale Burcu Özcan Keçeci’nin doktora tez çalışmasından üretilmiştir.

${ }^{2}$ Doç. Dr. - İstanbul Üniversitesi İletişim Fakültesi, fgoksu@istanbul.edu.tr

(iD ORCID: 0000-0001-8088-8326

3 Doktora Öğrencisi - İstanbul Üniversitesi İletişim Fakültesi, burcuozcan@gmail.com

(iD ORCID: 0000-0002-8361-685X
} 


\section{Giriş}

Kurumların farklılaşmak adına birbirleri ile yarıştığı günümüz koşullarında genel iş dünyasının yanı sıra karmaşık yapısı ile modern toplumun kültürel bir alt sistemi olarak görülen artık bir iş ve kar alanı haline gelen spor dünyasındaki aktörlerin de bir adım öne çıkmak adına çeşitli stratejiler takip etmesi gerekmektedir. Ekonomik alanda yapılan yatırımlar, borsada yapılan işlemler, endüstriyel alandaki faaliyetlerin yanı sıra alınıp satılma sürecinde spor ile ilgili kurumların da rakiplerini geride bırakmak adına sundukları hizmetleri farklılaştırmaları ve tercih edilir kılmaları için hedef kitleleri ile iletişime geçmeleri büyük önem taşımaktadır. Bu noktada pazarlama ve iletşşm faaliyetlerinin bir bütün olarak planlanması özellikle de ilişki ve iletişim kurma stratejileri içerisinde halkla ilişkiler fonksiyonlarının doğru bir şekilde yönetilmesi kurumlara ciddi bir avantaj sağlamaktadır.

İnsanlar ister aktif olarak sporu takip eden isterse normal bir izleyici ya da kat1limc1 olsun, zamanlarının kayda değer bir bölümünü spor odaklı okazyonlarda harcamaktadırlar. Spor salonları, parklar, sahil bölgeleri, dinlenme tesisleri, aktif izleyici olarak stadyum ya da spor salonunda izlenen karşılaşmalar, televizyondan yayınlanan canlı maçlar, spor programları, kösse yazıları, internet üzerinden yayınlanan videolar, sosyal medya mecraları üzerinden gerçekleşen her türlü içerik paylaşımı, e-spor karşılaşmaları, bilgisayar oyunları, vb. mecralar aracıllğı ile spor ve sporcuya ait enformasyonlar günlük yaşam içerisinde sürekli olarak izleyicilere sunulmaktadır. Burada aktif ya da pasif toplumun her kesiminden kişiler kendilerini iyi hissetmek, kilo almak ya da vermek, belli bir gruba dahil olup kendini bu ortamda tanımlamak, taraftar olma hissiyatını yaşamak, toplumla bütünleşmek, sosyalleşmek, sağlıklı yaşamak, gibi bir çok nedenle gün içerisinde belli bir sürelerini spor ile ilgili alanlara ayırmaktadırlar. Sporun geniş ölçekli bir iş kolu haline gelmesi, küreselleşme ile dünyanın küçülüp spor pazarının büyümesi, ulusal çaptan uluslararası bir pozisyona geçmesi ve endüstrileşen spor sektöründe teknolojik gelişmelerin de hızlı bir şekilde ilerlemesi sonucunda bu alanlar içerisinde gerçekleştirilecek iletişim çalısmaları büyük önem teşkil etmektedir. Artık, daha önce taraftarlara yönelik spor etkinliklerinin reklamının yapılması ile sağlanan tek yönlü iletişim boyutunun ötesine geçilmekte, spor kulübünün tüm hedef kitleleriyle tüm iletişim kanallarını odaklı bir şekilde kullanarak karşılıklı olarak iletişim kurulmaktadır.

Bütünleşik pazarlama iletişiminde satış promosyonu, doğrudan pazarlama, halkla ilişkiler, reklam, sponsorluk gibi farklı iletişim disiplinlerdeki çeşitli fonksiyonlar bir araya getirilerek maksimum iletişim hedefi ile hareket edilmektedir. Özellikle halkla ilişkiler çalışmaları her ne kadar iletişimi ve kuralları ayrı bir disiplin içerisinde hareket etse de pazarlama iletişiminde de bütüncül bir iletişim için birlikte hareket edilen önemli bir iletişim disiplini olmaktadır. Halkla ilişkiler, satış ve pazarlama odaklı iletişime katkı sağladığ1 gibi doğru mesajların çift yönlü iletişime olanak tanıyan bir çerçevede hedef kitleler ile paylaşılması aracıllğı ile kurum imajı oluşturulması, kurum imajın pekiştirilmesi, etkileşime açık bir iletişim kurulması, güven oluşturulup sadakatin yaratılması vb. gibi hedefler ile bütüncül bir iletişim anlayışı çerçevesinde pazarlama iletişiminin vazgeçilmez unsurlarından birini teşkil etmektedir. Pazarlama iletişimi kapsamında spor takımları gerçekleştirdikleri iletişim süreçlerinde mecra ve ürün olarak hedef kitlelerinin ilgili oldukları alanları kullanmalarının yanı sıra kurum ya da ürün algısını belli bir yöne çevirmek adına da çeşitli imaj, söylem ve sloganlardan faydalanabilmektedirler. Spor markalarının sıklıkla kullandığı bu iletişsim stratejisi 2007'de tenise yönelik ilginin artması amacı ile gerçekleştirilmiştir. 4 adet reklam filmi ve billboardlarla tenisin popülerliğini artırmak için başlanılan "Feel it " kampanyası özellikle Shangai'daki sezon sonu turnuvasından etkilenerek Çin mitolojine yönelik bir atıfla oyuncuların güçlerini efsanevi hayvanlarla eşleştirmektedir. Kampanya, tenisin globalleşmesi yönündeki hedefiyle paralel olarak oyuncuları bu dünyanın ötesinde oynayan titanlar olarak betimlemektedir.

\section{Spor İletişimi}

Tüm sınırların kalktığı ve serbest bir iletişim akışının olduğu küreselleşen dünyada spor artık eski olimpiyat ruhunun yer aldığı ve amatör ruhun her şeyden önde geldiği bir olgu değildir. Spor yalnızca spor ya da hobi olmaktan öte ticarileştirilmiş ve meta haline getirilmiş, sahaların reklam alanı, oyuncuların da kasa olarak görüldüğü kar elde etmek için yatırım yapılan bir alandır. Burada Habermas ve Adorno'nun ortaya koyduğu "boş zaman" kavramına tekrar bir geri dönüş yapmak gerekmektedir. Kapitalizmin kontrolünde olan ve egemen güçlerin var olan yapıyı devam ettirmek üzere kitlelere boş zaman aktivitesi olarak sundukları eğlence araçları aslında yine baskın sistemi devam ettirmeye yarayan kaçış alanları olarak görülmüştür. Adorno ve Horkheimer boş zaman kavramı ile bağlantılı olarak spor alanı hakkında da bazı görüşler bildirmişlerdir. Adorno'nun ifadesiyle "spor makinenin ondan alıp götürdüğü işlevlerin bazılarını insanoğluna geri verir, ama yalnızca makinenin hizmetinde onu insafsızca tasnif etmek için" (Akt: 
Bammbery, 2005, s. 351) aynı şekilde Habermas da "spor bir serbest zaman faaliyetidir - işin devamını görür" demiştir (Akt: Voigt, 1998, s. 115).

Marksist bir bakış açısıyla yaklaştığımız küreselleşme olgusu Althusser'in "Devletin İdeolojik Aygitları" olarak tanımladığı aile, hükümet, ordu, okul, din, sendikalar, vb. aygıtlardan biri haline gelmiştir. Egemen olan sinıfin tekelinde bulunan spor artık devletin kültürel bir ideolojik aygitı olarak hareket etmekte, toplumdaki egemen ideolojinin oluşmasında ve yayılmasında büyük rol oynamaktadır.

Görüldüğü üzere, küreselleşmenin etkisi ile birlikte spor artık yalnızca spor olmaktan çıkmış devletler ve küresel șirketler tarafından reklam ve propaganda aracı olarak kullanılmıştır. Yetim'in (2005) de belirttiği gibi toplumların bugün oynadıkları büyük propaganda savaşında spor, en büyük ilgiyi çeken hem de dil problemlerini aşarak bireylerin ve toplumların başarılarını geniş kitlelere en kolay anlatabilen, aktaran sosyal bir olgudur (Yetim, 2005, s. 130). Ayrıca spor bir yandan uluslararası ilişkileri geliştiren bir barış aracı olarak algılanırken diğer yandan ulusların birbirlerine üstünlüğünü kabul ettirmeye çalıştığı soğuk savaş aracı olma özelliği de taşımaktadır (Öztürk, 1998, s. 33). Tarihsel süreçte sporun güç gösterisi olarak kullanıldığ1 durumlara örnek olarak çift kutuplu dünya düzeninin olduğu dönemde iki kutup arasındaki üstünlüğü ortaya koymak için bir araç olarak kullanılmıştır.

Sporun hızlı gelişimi ve eş zamanlı olarak yaşadığı dönüşüm spor alanı ile etkileşimde bulunan tüm alanları etkilemiş ve değişime uğratmıştır. Özellikle 1960’lı yılların sonlarından itibaren spor ile ilişkili işletmelerin, sportif eşya üreten firmaların, kitle iletişim araçlarının, spor alanlarının, stadyumların, sportif ticari ürün üreten firmaların, sporcuların, profesyonel ve amatör liglerin spor alanı içerisinde büyümesi, sporu sadece bir endüstri haline getirmekle kalmamış, endüstri içerisinde sektörel büyümeyi de oluşturmuştur (Argan ve Katırc1, 2015, s. 24). Özellikle tüm dünyanın ortak bir paydada birleştiği, büyük kitleleri peşinden sürükleyen bir spor dalı olan futbol alanında bu gelişimler daha gözle görünür bir şekilde yaşanmaktadır.

1987 yllinda 50 sektör arasında 23. sırada yer alan küresel spor endüstrisinin 2017' de profesyonel 100 milyar, toplamda ise 600 milyar doları bulduğu; içerisinde, şirketleri, çalışanları, tesisleri, cirosu ve ortak çalıştığ1 tüm alanları etkileyen ve dünya liginin en fazla gelir elde eden 20 futbol kulübünün bile 2017-2018 Deloitte Futbol Para Ligi verilerine göre bir önceki sezona oranla \%6'lık artışla 8,3 milyar avroluk bir ciroya sahip olduğu bir yapıda yalnızca sportif başarıların kulüplerin marka değerini yükseltme konusunda yetersiz olduğu açıkça ortadadır. Günümüzde bu başarıların yanı sıra, daha fazla gelir elde edip daha fazla taraftar kitlesine hitap edebilmek, taraftarlarla etkin ve deneyimsel ilişki geliştirmek, yıldız isimlerin transferleri ve yapılacak tüm etkinlikler ile daha da popüler hale gelmenin zorunlu olduğu bir dönem içerisinde, iç ve dış kamulara yönelik gerçekleştirilecek iletişim çalışmalarının önemi de artmaktadır.

Diğer taraftan, spor kuruluşları daha agresif ve daha stratejik bir iletişim planları yapmakta, yerel olduğu kadar uluslar arası ölçekte de pozitif imaj sağlama çabası gütmektedirler. Spor kuruluşlarının maddi gücü ile medya birbirine bağlı durumdadır, dünya çapında New York Rangers, Knicks, Liberty, Madison Square Garden'ın sahibi Cablevision; Atlanta Braves ve Sport Illustrated'in sahibi Time Warner ve ESPN'in sahibi Time Warner gibi büyük medya holdingleri de spor alanına yatırım yapmaktadır.

\section{Sponsorluk Kavramı ve Tarihsel Gelişimi}

Sponsorluk tarihi İ.Ö Eski Yunan'a kadar uzanan bir süreçten bugünümüze ulaşmıştır. Çeşitli kaynaklara göre eski yunanda vergi mükellefi zengin vatandaşlar büyük çaplı karşılaşmaları ve toplumun katıldığı festivallere destek vermek adına finansman sağlamış; aynı zamanda ödenen yüksek vergiler de Atina ve Olimpiya'nın ekonomik ve kültürel gelişimine teşvikte bulunmuş bu da tarihteki ilk sponsorluk çalışmalarından biri olarak belirtilmiştir. Yüksek vergi ödenmesinden duyulan onur, bazı kişilerin bu vergi ödemesini gönüllü hale getirmiş ve hatta bu kişilere toplum tarafindan büyük sayg1 gösterilerek isimleri mermer levhalara kazınmıştır. Arkeologların yaptıkları çalışmalara göre Olimpiya'ya bağış yapan en eski isim “"Leonidas” tır. İ.Ö. 330 döneminde prestijli ziyaretçiler ve resmi misafirler için inşa edilen lüks binaları finanse etmiş ve bu binalar "Leonidaion" adı verilerek sponsor olan kişi/aile ile anılmıştır. Bu destek çalışması "İsim hakları" konusunda belgelenen ilk örnek olma özelliği taşımaktadır" (Kissoudi, 2005). İ.Ö 264'te ilk gladyatör mücadelesi yapılmış, bu karşılaşmalar zenginliğini göstermek ve toplumu etkilemek isteyenler tarafindan finanse edilmiştir. Karşılaşmaların reklamı şehirdeki binalarda yapılmış, organizasyona finansal destek veren kişiler ve etkinlik, gladyatörlerin güçleri hakkına bilgilendirme broşürleri dağıtılmış ve biletler caddelerde satılmıştır. Gladyatörlerin niteliksel ve niceliksel büyüklükleri ile 
şovun büyüklüğü finansal desteğin de büyüklüğü olarak karşılık bulmaktaydı (https://elevent.co). Julius Cesar da hem kaybettiği kızı anısına hem de Mısır ve Galya bölgesindeki zaferlerinin altını çizmek ve gücünü göstermek amacıyla turnuvaya destek sağlamıştır.

Ortaçağ Rönesans döneminde himaye altına alma bakış açısıyla başlayan sponsorluğun yola çıkış noktası, imparator ve ileri gelen himayeci ailelerin kişisel zevki, sanata olan bakış açıları ve din unsurları doğrultusunda bir zemine oturmuştur. Sanat alanında ağıllık gösteren bu destekleme faaliyetleri, zaman içerisinde eksenin farklı yöne çevirmiş ve ticari hedefler doğrultusunda şekil değiştirmiş̧tir. "Ticari amaçlı ilk sponsorluk 18. Yüzyıl ortalarında gerçekleşmiştir. Bozkurt'un (2005) "İletişim Odaklı Pazarlama" kitabında yer alan bilgiye göre kullanımı Romalılar ve Yunanlılara kadar uzanan sponsorluğun ilk resmi örneği, 1861'de bir Avustralya firması olan Spiers and Pond'un Avustralya'nın İngiltere ile olan ilk turuna sponsor olmasıdır. 1887 yılında Fransız dergisi "Velocipe de" ilk otomobil yarışını finanse etmiştir (Bülbül, 2004, s. 70). 1896, 1928 ve 1984 y1llarındaki Olimpiyat oyunları ile 1982 İspanya Dünya Futbol Kupas1 özellikle spor sponsorluğu konusunda milat olmuş ve ilerleyen senelerde gelişerek bugünkü sponsorluk çalışmalarına zemin oluşturmuştur.

Sponsorluğun Türkiye'deki tarihine bakacak olursak, aynı eski Roma'daki gibi padişahların karşıllksız gerçekleştirdikleri bağışlar karşımıza çıkmaktadır. "Özellikle Osmanlı döneminde, padişahlar kültür ve sanat alanının koruyuculuğunu üstlenmişler ve bu alanda yetenekli olan bazı kişileri saraylarına alarak bunların hizmetlerinden faydalanmışlardır (Akyürek, 1998, s. 112). Osmanlı döneminde padişahların desteği ile başlayan süreç kurulan bazı vakıflarla devam etmiştir.

Cumhuriyet döneminin ilk sponsorluk girişimi de Atatürk tarafından başlatılmışıır. Üstü açı spor bir uçakla okyanusu geçmeyi tasarlayan John Polanda ve Russel Bortman adlı iki macerapereste, Atatürk'ün girişimi ile Türkiye sponsor olmuştur. Mali durumu hiç de iyi olmayan Türkiye'nin, dünya çapında tanınma ihtiyac1 yüzünden yaptığ bu sponsorlukta, iki kafadar, 28 Temmuz 1931 günü aralıksız tam 49 saat 5 dakika uçarak rekor kırmışlardır. Proje beklenilenin de üzerinde, dünya gündemine oturmuş, olay ve Türkiye günlerce dünya basınının konusu haline gelmiştir (Okay ve Okay, 2002, s. 26). Cumhuriyet tarihinden günümüze kadar gelen ve devam eden tüzel kişiliklerin destekleme faaliyetlerine katılmas1 bugünkü sponsorlukların yolunu açmış; Türkiye'de de Sabancı, Koç, Ayhan Şahenk, Eczacıbaşı, Fevziye Mektepleri, İzzet Baysal, Anadolu Eğitim ve Sosyal Yardım vakıfları hayırsever şirket sahipleri tarafından kurulmuş, mesenlik ve bağış̧̧lık kavramları dahilindeki hizmetleri çağdaş anlayışla toplum yararına sunmaktadırlar.

Sponsor tüm yaptıklarına, sponsore edilenin de karşılık vermesini bekler. Bağışta bulunan kurum bağışa karşıllık beklemez (Peltekoğlu, 2005, s. 218). Sponsorluk çalışmaları, destekleme faaliyetleri, toplum yararına ve fayda yaratma amacıyla mesenlikle ortak paydada buluşmakta iken, sponsorluk faaliyeti içinde bulunan kurum ve markaların ticari ve imaj odaklı hedefleri doğrultusundaki amaçlanı ile de mesenlikten ayrılmaktadır. Özünde mesenlik yaklaşımının yer aldığ1 sponsorluk, günümüzde ticari bir eksen üzerinde kurum ve marka avantajına yönelik 360 derecelik bir iletişim çalışması ile gerçekleştirilmekte ve mesenlik/bağış̧̧ılıktan farklılaşmaktadır. Kısaca bu başlıkları birbirinden ayırmak ve sponsorluk olup olmadığını belirlemek için yapılan faaliyetin tanıtım, kar gütme ve karşılık beklenti doğrultusun da yapılıp yapılmadığını, aynı zamanda tanıtım ve reklam faaliyetlerinde kullanılıp kullanılmadığına bakmak gerekmektedir.

Sponsorluk, bir olay yada faaliyet için direk bir kuruluş yerine bir organizasyon tarafindan bir olaya ya da faaliyete yönlendirilen (para, insan gücü, ekipman vb.) kaynakların karşılanması olarak tanımlanmıştır. Başka bir ifadeyle sponsorluk, yer ve zaman satın almaksızın işletme amaçlarına yönelik olarak kitle iletişim araçlarındaki gösteri ve olaylara yapılan yatırımlardır (Karadeniz, 2009). Bir tanıma göre sponsorluk, kurumsal ya da pazarlama amaçlarına yönelik, doğrudan medya kanallarını satın almadan gerçekleştirilen olay ya da nedenler için yapılan ticari bir yatırımdır (Akyürek, 1998, s. 6). Bir diğer tanıma göre ise sponsorluk, spor, eğlence, kar amacı gütmeyen olaylar veya organizasyonlar gibi bir mala ödenen nakdi ve/veya ayni ücret ve bunun karşıllığında mal ile ilişkilendirilmiş ticari potansiyelin işletilebilirliğine ulaşılan bir faaliyettir (Kelvey ve Grady, 2008, s. 551).

Sponsorluğun üzerinde genel olarak uzlaşılan tanımlarından biri de Pope (1998) tarafından kaleme alınmıştır. Sponsorluk, kurumlar tarafindan direkt olarak kişi, uzman ya da faaliyete yönelik, sponsorun promosyon stratejisi doğrultusunda fayda sağlayacak aktivitelerin kurumsal, pazarlama ya da medya amaçları ile doğru orantılı olarak ifade edilmesi yoluyla para, insan, ekipman gibi kaynakların bir kurum ya da organizasyon (sponsor) tarafından karşılanmasıdır (Pope, 1998). 
Literatür araştırmalarında sponsorluğun tanımı ile ilgili birden fazla yaklaşım bulunmakla birlikte, genel olarak günümüz sponsorluk çalışmalarının, kurum ve kuruluşların iletişim stratejileri, farkındalık yaratımı, tanınırlık sağlama, kar elde etme, reklam, satış, tutum ve davranış değişikliği ile birlikte imaj yönetimi amaçları doğrultusunda bir ya da birden çok alanda (spor, sanat, çevre, sağllk, etkinlik, vb.) gerçekleştirdikleri pazarlama iletişimi ve halkla ilişkiler odaklı destekleme faaliyetleri olarak betimleyebiliriz.

\section{Spor Sponsorluğu İletişimi}

Sponsor firmalar ürün ve hizmetlerinin tanıtımları adına gerçekleştirdikleri spor sponsorlukları dahilinde hem kendi marka, ürün veya hizmetlerine yönelik tanıtım amaçlarına hizmet etmekte hem de gerçekleştirdikleri iletişim faaliyetleri ile de ilgili spor branşı ya da organizasyonunun tanıtım ve pazarlamasina hizmet etmektedirler.

Küresel çaptaki organizasyonlar sponsorların gerçekleştirdiği tanıtım çalışmaları için avantajlı bir zemin hazırlamaktadır. Örneğin dünya kupası birçok marka için reklam ve tanıtım konusunda geniş opsiyonlar sunarken, yapılan pazarlama ve iletişim çalışmaları da oldukça ses getirmektedir. 2010 Dünya Kupası öncesi Louis Vuitton futbolun ünlü marka oyuncuları Pele, Maradona ve Zidane ile reklam kampanyas1 hazırlayıp katalog çekimi gerçekleştirmiştir (https://www.campaignlive.co.uk). Johannesburg'da gerçekleşen 2010 Dünya Kupası finalinde de ses getiren bir reklam kampanyasına imza atmıştır. Bir önceki dünya şampiyonu İtalya Milli Takımı'nın kaptanı Fabio Cannavaro, Louis Vuitton bir sandıkla izleyicilerin önüne çıkmış kupa sahaya Louis Vuitton bir sandık içinde gelmiştir (http://brandsandfilms.com). Tenis, yelken, kriket ve binicilik gibi sporlara da sponsor olarak yer alan FIFA'nın resmi sponsorlarından Emirates Havayolları da dünya kupasına destek vermiştir. Sponsorluk çerçevesinde yaptığı tanıtım çalışmalarında FIFA Dünya Kupası seyahat paketleri satmış, Emirates'e ait bekleme salonlarında maç yayınlarına olanak vermiş, uçak içi yayınlarda maçları canlı ya da tekrar olarak yolcularla buluşturmuş ve en çok ilgi gören maçlarda da pilotlar uçuş esnasında canlı sonuçları açıklayarak dünya kupası ile ilgili gelişmeleri an be an taraftarlar ile buluşturmuşlardır (https://www.emirates.com, https://www.aviationbusinessme.com).

Dünya kupası dahilinde gerçekleştirilen bir diğer iletişim çalışması da Coca Cola'nın oyuncuların gol kutlamaları ile ilgili gerçekleştirdiği çalışmadır. Dünya kupası esnasında oyuncuların gol kutlama sevinçleri www.fifa.com/celebrations isimli özel web sitesine yüklenmiş ve taraftarlardan bu görüntülerden en beğendikleri kutlamayı çevrim içi olarak oylaması istenmiştir. Kazanan kişi Coca Cola Kutlama Ödülü ile ödüllendirilmiştir (https://investors.coca-colacompany.com). Coca Cola burada gerçekleștirdiği taraftar iletişiminin yanı sıra 2015 ylına kadar gerçekleştirilen ve Afrika'da yaşayan yaklaşık 2 milyon insan için temiz su ve sıhhi temizlik amacı ile oluşturulan "Okullar İçin Su" projesi ile de sosyal sorumluluk çalışmasına imza atmıştır. Bu doğrultuda her bir oyuncunun kutlama girişimi için Coca Cola "Okullar için Su" projesine 1500\$ katkı sağlamışıtı (https://www.fifamuseum.com). Ayrıca kazanan oyuncu adına da aynı projeye ekstra olarak 50.000\$ bağışlamıştır (https://www.businesswire.com).

Sponsorların gerçekleştirdiği iletişim çalışmalarında yıldız oyuncular sıklıkla kullanılmakta ve sporun doğasında yer alan itici güç, sağlık, performans, hız, rekabet, vb. gibi öğeler de marka iletişimlerinde altı çizilen öğeler olmaktadır. Dünya çapında spora verdiği destekle tanınan Castrol markası, 2009 yılından bu yana dünya çapındaki futbol elçisini Cristiano Ronaldo olarak belirlemiş ve hem dünyada hem de Türkiye'de eş zamanlı olarak güçlü performansların muhteşem buluşması teması üzerine yapılandırılan reklam filminde ünlü oyuncuyu kullanmıştır. Markanın çeşitli spor iletişim aktivitelerinde de futbol elçisi Ronaldo ana aktör olarak kullanılmıştır. Castrol'ün dünya çapında organize ettiği "Ronaldo'ya Meydan Oku" yarışmasına dünyanın dört bir yanından gelen medya mensupları ve futbolseverler katılmıştır. "Castrol EDGE Ronaldo'nun Sinırlarını Test Ediyor" belgeselinde, yıldız oyuncunun yetenekleri, gücü ve çevikliği, futbol sahasından laboratuvara taşınarak dünyanın önde gelen spor bilimcileri tarafindan sınanmış; Ronaldo'nun yeteneklerinin ve gücünün sinırları zorlanarak meslektaşlarından neden farklı olduğu ortaya konmuştur. Burada hem bireysel sporcu sponsorluğu hem de yldız sporcuların reklam ve tanıtım faaliyetlerinde nasıl kullanıldığı net bir şekilde görülmektedir.

UEFA EURO 2012 ${ }^{\mathrm{TM}}$ ve FIFA World Cup 2014 ${ }^{\mathrm{TM}}$ organizasyonlarının da Resmi Sponsoru olan Castrol ayrica 2008 yllinda "bilimsel verilerle analiz" kapsaminda www.castrolfootball.com sayfas1 üzerinden EURO 2012 Avrupa Futbol Şampiyonası'nın, Avrupa'nın 5 büyük liginin performans ve oyuncu istatistiklerini yayınlamaktadır. Ayrıca, ulusal lig maçlarının analizleri ile futbolcular ve takımlarla ilgili de karş1ılklı özel analizler hazırlamaktadır. Her maç sonrasında, oyunculara Castrol Analistleri’nin 
ölçümlere dayanarak hesapladığı ve 10 puan üzerinden değerlendirilen Castrol EDGE Endeks puanı verilmektedir. Elde ettikleri performans puanlarına göre 2000'den fazla futbolcunun siralaması her ay castrolfootball.com üzerinde yayınlamakta ve o ayın en iyi performans puanını elde eden oyuncusu açıklanmaktadır. Bu bilgilerin yanı sıra www.castrolfootball.com'da, Castrol futbol elçileri Sir Alex Ferguson, Marcel Desailly, Cristiano Ronaldo gibi oyuncuların yorum ve analizlerine de yer verilmektedir. Sosyal paylaşım siteleri de iletişim anlamında güçlü olarak kullanılmakta, Facebook (facebook.com/castrolfootball) ve Twitter (twitter.com/castrolfootball) üzerinden de futbol üzerine takiplerini gerçekleştirmektedirler. İletişim çalışmalarında çok yönlü iletişimi tercih eden ve farklı platformlarda tüketicilerle buluşan Castrol, Castrol Endeks EURO 2008 süresince taraftarlara, ilk defa oyuncuların nasıl performans sergilediklerini objektif olarak izleyerek karşılaştırma yapmalarına olanak sağlamıştır. 2008'den bu yana hazırladığı istatistiklerle futbol dünyasında bilimsel analizden söz eden Castrol UEFA Euro 2012 sponsorluğu için son on altıya kalacak takımları tahmin etmek üzere, takım ve oyuncu performansını ölçen Castrol Tahminci'yi de 7 Şubat 2010'da yapılan eleme kuralarının öncesinde duyurmuştur. Taraftara yönelik ayrıca, taraftarların oyuncu performanslarını değerlendirmeleri amacı ile verilerden yararlanılarak hazırlanan Castrol Klasmanı (Castrol Ranking) çalışmasını da hayata geçirmiştir (https://www.uefa.com).

Sponsorluk aracıllğı ile yapılan iletişim çalışmaları küresel anlamda oldukça rağbet görmekte ve sponsorluk alanında yapılan harcamalar gün geçtikçe artış göstermektedir. Amerika'da yayınlanan IEG Sponsorship Report adı altında sektörün en önemli raporları olarak gösterilen analizleri sunan "www.sponsorship.com" sitesinden alınan bilgiye göre, dünyadaki sponsorluk harcamaları 2014 y1lında 55.3 milyar dolar iken 2015 yllinda yüzde 4,1 büyüme ile 57,5 milyar dolara, 2016 yllinda 60,1 milyar dolar gibi bir harcama yapılmışken 2017 yllında yüzde 4,3lük bir artışla 62,7 milyar dolar seviyesine yükselmiştir. Forbes ve Statista portal verilerine göre de 2018 yllı sponsorluk harcaamaları yaklaşı 65,8 milyar dolar gibi bir rakama ulaşmıştır. IEG verilerine göre dünyadaki sponsorluk harcamalarının en büyük payı $36,7 \%$ Kuzey Amerika'ya aitken bunu sirasiyla, 26,7\% Avrupa, 25,2\% Asya Pasifik ülkeleri, 7\% Orta ve Güney Amerika ile 3,8\% Türkiye'nin de içinde bulunduğu diğer ülkeler izlemektedir (IEG Sponsorship Report, 2018).

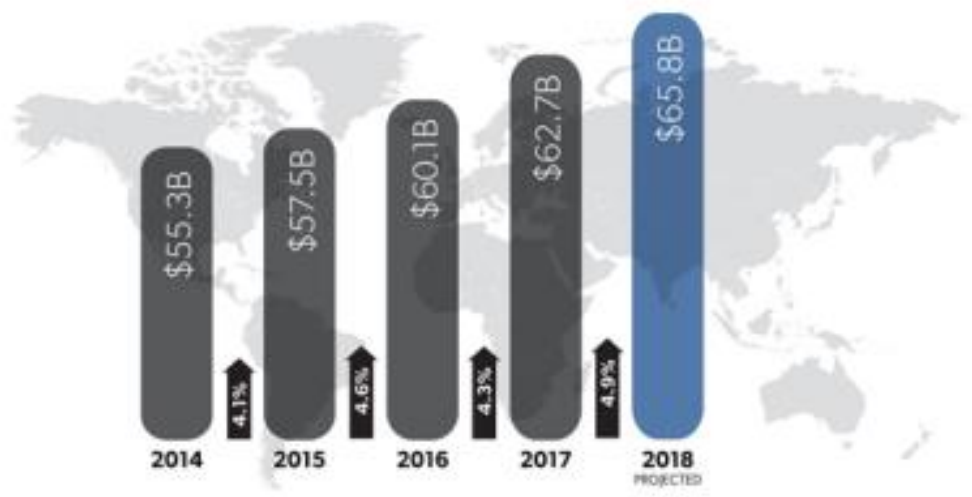

\section{Şekil 1. Toplam Küresel Sponsorluk Harcamalarn (Kaynak: 2018 IEG Sponsorship Report)}

En çok yatırım alan alanlardan biri olan spor sponsorluğunda çok sayıda şirket ana ve resmi sponsorluk kapsamında çalışmalar yapmaktadır. Örneğin Türk markalarından Beko, "Dünya markası" mesaj ve imajını pazarlama doğrultusunda yaptığı çalışmalar kapsamında FC Barcelona’nun resmi sponsorluğunu yaparken Dünya ve Avrupa Basketbol şampiyonalarının yanı sıra İtalya Basketbol Ligi, Türkiye Basketbol Ligi, Fenerbahçe Spor Kulübü basketbol takımının da ana sponsoru olarak iletişim faaliyetlerini sürdürmüştür.

Türkiye'de aktif sponsorluklara örnek olarak ilk akla gelen firmalara, Beşiktaş Spor Kulübü ile uzun süreli işbirliğine imza atan hem stadyum adı hem de forma sponsorluğu ile ciddi maddi destek ve eş zamanlı olarak da pazarlama iletişimi çalışmaları ile spor alanına yatırım yapan ve aynı zamanda gençlik iletişimi kapsamında Freezone çatısı altında genç yetenekler ve müzik iletişimi alanına destek veren Vodafone'u örnek verebiliriz. Ayrıca, spor alanında hem ulusal hem uluslararası çapta bütçe ve iş gücü ayıran Türk Hava Yolları, basketbol sporuna aktif bir şekilde destek veren Beko, Opet, Coca Cola, vb.'i örnek gösterilebilir. 


\section{Türkiye'de Pazarlama Odaklı Spor Sponsorlukları}

Günümüzde spor, futboldan basketbola, tenisten yüzmeye, voleyboldan atletizme, golften hentbola ve daha bir çok dalın dahil olduğu 2018 verilerine göre 600 milyar doları aşan bir endüstri olarak hizmet vermekte ve her branşı ile geniş kitleler tarafindan takip edilmektedir. IEG Sponsorluk Raporuna göre 2017 yllında dünya sponsorluk pazarı 62,7 milyar dolarken 2018 yllında ise 65,8 milyar dolar olarak belirtilmiştir (https://www.statista.com). 2017 verilerine göre Türkiye'nin de içinde bulunduğu Avrupa pazarındaki sponsorluk büyüklüğü 16,7 milyar dolar olarak bahsedilmekte, Türkiye'de ise 1,1 milyar dolarlık bir sponsorluk pastası olduğu ve bunun 770 milyon dolarının spor endüstrisine ve bu payın \%55'inin ise spor kulüplerine yönelik olduğu belirtilmektedir (Akt: Şentürk ve Selvi, 2019, s. 135).

Literatür taramalarına göre, spor sponsorluğunun ilk uygulamalarının, eski Yunan'da ve Roma'da uygulandığı ileri sürülmektedir. Bu uygulamalarda Eski Yunan ve Roma aristokrasinin amacı, sporcuları (gladyatörleri) destekleyerek kendi sosyal statülerini yükseltmek olarak belirtilmektedir (Sandler ve Shani, 1993; Cornwell, 1995). Kullanımı Romalılar ve Yunanlılara kadar uzanan sponsorluğun ilk resmi örneği, 1861'de bir Avustralya firması olan Spiers and Pond'un Avustralya'nın İngiltere olan ilk turuna sponsor olmasıdır (Bozkurt, 2005, s. 318). 1896 Olimpiyat Oyunları'nın resmi programına reklamların yerleştirilmesiyle, sponsorluğun ilk defa ticari kullanımı gerçekleşmiş, Coca-Cola tarafindan 1928 Olimpiyatları'nda, ilk olarak örnek ürün dağıtımı hakları alınmıştır. 1975'li yıllardan sonra, sponsorluğun bugünkü alg1landığ1 biçimiyle çağdaş kurumsal spor sponsorluğu görülmeye başlanmıştır (Okay ve Okay, 2005, s. 445). Çağdaş anlamda spor sponsorluğu uygulamalarının yoğun olarak başlamas1 1975'de, olimpiyat oyunlarında ise 1976 Montreal Olimpiyat Oyunları ile başladığı, 1984 Los Angeles Olimpiyat Oyunlarında ise önemli artışların yaşandığı ortak spor sponsorluğunun da yine bu tarihlerde başladığ1 araştırmacilar tarafindan belirtilmektedir (Meenaghan, 1991, Sandler ve Shami, 1993, Stotlar, 1993).

Spor endüstri uzmanlar1 1984 yllinda düzenlenen Los Angeles Olimpiyat Oyunlarını spor sponsorluğunun gelişimi adına bir dönüm noktası olarak tanımlamışlardır. Oyunlarda ilk defa 1984 Los Angeles Olimpiyat Oyunları Komitesi'nin yaptığ1 yeni düzenleme ile kara geçme başarısı göstermiştir. Organizasyon komitesi pahalı tesisler yapma yerine, 1932 yllinda Olimpiyatlara ev sahipliği yapmış olan Los Angeles şehri, sahip olduğu 1932 Olimpiyatlarının yapıldığı Momerial Coliseum Stadını yeni ihtiyaçlara göre tanzim etti. Üniversite binaları kiralanarak olimpiyat köyü yapılma masrafindan kurtuldu. Los Angeles Olimpiyat Oyunlarının toplam hasılatı 786 milyon dolara erişti. Toplam masraf 545 milyon dolar da kalarak ilk defa olimpiyat oyunları 236 milyon dolar artı bakiye biraktı. 1992 yılı Olimpiyat oyunlarına 6 ülke birden talip olmuştur (Olimpik Hareket, 1988, s. 66). Ardından yine aynı strateji ile Beyzbol Ligi’nde kurumsal sponsorluk anlaşmasına imza atılmıştır. Bu strateji doğrultusunda sponsor firmalar ile üç seneden az olmamak kaydı ile anlaşma sağlanmış olup, beyzbol ligini desteklemek ve tanıtmak adına yıllık en az 2 milyon dolarlık bir reklam bütçesi, ayrıca ligde oynayan tüm takımlara bölüştürülmek üzere 2 milyon dolarlık ayrı bir bütçe ile 1 milyon dolarlık ayni sponsorluk bütçesini ayırmakla yükümlü kılınmışlardır (Masteralexis ve Hums, 2018. 365). Dönemin ana sponsorları Coca Cola, Chevrolet, Equitable, Fuji Photo Film USA, Kellogg's Leaf Candies, Mastercard ve USA Today gibi Amerika Birleşik Devletleri'nin önde gelen şirketleri olmuştur.

9 Haziran 2010 tarihli Hürriyet gazetesinden edinilen bilgi doğrultusunda Türkiye'deki spor sponsorluğu alanında yapılan ilk uygulama 1931 yılında gerçekleşmiştir. 1930 yilında Amerika'da John Polanda ve Russel Bortman adlı iki macera sever, üstü açık spor bir pir pır uçakla okyanusu geçmeyi düşünmekte ve bu deneme ile havada kalma ve en uzun noktaya uçuş rekorunu kırmayı amaçlamaktadırlar. Projenin maddi olarak desteklenmesi gerektiği bilgisi Türkiye'ye ulaştığı dönem Türkiye'nin de dünya çapında tanınması gereken döneme rastlamaktadır. Bu çerçevede Türkiye, konuyla ilgili desteğini vermiş ve bu deneme uluslararası basının ilgisini çekmiştir.

Dünyada Coca Cola, Cadburys, Nike, Adidas, Pepsi, Barclays, Budweiser, Heineken, Aon, AT\&T, Mastercard, Gilette, vb., bir çok büyük marka spora destek vermektedir. Finanstan, alkollü içeceğe, gıdadan spor teçhizatlarını sağlayan markalara, kişisel bakım ve hızlı tüketim mallarına kadar geniş bir alanda yer alan dünyaca ünlü markalar iletişimlerini spor sponsorluğu üzerinden kurgulamaktadır. Türkiye'nin önde gelen şirketleri farklı iletişim ve pazarlama hedefleri doğrultusunda bireysel sporcu sponsorluğundan, lig sponsorluğuna, takım sponsorluğundan federasyon sponsorluğuna, organizasyon sponsorluğundan resmi tedarik sponsorluğuna kadar geniş bir yelpazede sponsorluk çalışmalarını yürütmektedirler. Türkiye'de en fazla takip edilen spor dallarından futbol, basketbol ve voleybol dallarında 
sponsorluk çalışmalarının en fazla göze çarpan örneklerine kabaca bakıldığında, Türkiye'de GSM operatörü ve teknoloji şirketi olarak faaliyet gösteren Turkcell, 2005 yllinda futbol süper ligine ismini vermiştir. Sponsorluğun firmalar ve spor sektörü adına olumlu geri dönüşler sağlaması ile birlikte diğer şirketler de sponsorluk anlamında yatırımlara başlamış ve Süper Lig 2010 yilı itibari ile "Spor Toto Süper Lig "olarak anılmaya başlanmıştır. Bunun yanı sıra futbol 1. Ligi de "Bank Asya" adını alırken (anlaşma 2012 yilında sona ermiş, 2016 yılına kadar PT'T 1.Lig adını almıştır. Eylül 2016'da anlaşmanın sonlanması ile yeniden TFF 1.lig adını almıştır) 2. ve 3. Ligler de "Spor Toto Ligi" olarak adlandırılmıştır. Sponsorluk alanında global olarak spora destek veren Türkiye Futbol Federasyonu ana sponsorlardan Coca Cola da "Akademi Lig"lerine ismini verirken, "Plaj Futbolu" Garanti Bankası ismi ile, "Futsal Ligi" Efes markas1 ile "Halı Saha Ligi" de Nike markası ile telaffuz edilmiştir. Türkiye Kupası 2005-2009 y1lları arasında "Fortis Türkiye Kupası" adıyla anılırken 2009 yll itibari ile "Ziraat Türkiye Kupası" olarak ifade edilmektedir. Basketbol Liginde ise beyaz eşya sektörünün önemli oyuncularından Beko markasını basketbolla özdeşleştirerek ismini 2006/2007 sezonu itibari ile basketbol ligi ile bir araya getirmiş, meyve suyu pazarında faaliyet gösteren Aroma ise voleybol ligine ismini vermiştir. Tahincioğlu Holding Basketbol Super Ligi'ne isim verirken "All Star" organizasyonu da bu isimle anılmıstır. Garanti Bankası 2001 yllından itibaren sürdürülebilir iletişim çalışmalarının bir alanını da spor sponsorluğunda gerçekleştirerek basketbol A Milli Erkek, A Milli Kadın ve Altyapı Milli takımlarına destek vermiş aynı zamanda 12 Dev Adam Basketbol Okulları (12 DABO) projesini gerçekleştirmiştir. Vestel, Türkiye Voleybol Federasyonu'nun ana destekçisi olarak "Sultanlar Ligi”"ne ismi vermiş, "Efeler Ligi", "Kupa Voley", "Pro Beach Tour" gibi organizasyonlara da destekte bulunmuştur. Ana destekçilerin yanı sıra, finans, telekomünikasyon, yakıt, sigorta, otomotiv, havacılık, spor giyim, hızlı tüketim malları, temizlik ve sağlık ürünleri, yiyecek-içecek şirketleri, bahis şirketleri, vb., bir çok alanda spor yatırımı yapan markalardan söz edebiliriz.

\section{Yöntem}

Türkiye'deki spor iletişim çalışmaları kapsamında yapılan spor sponsorluğu çalışmalarını ve etkilerini anlamak için araştırmada betimsel analiz yöntemi kullanılmıştır. Betimsel analiz, araştırmacıların çalışılan farklı olgu ve olaylar hakkında özet bilgi elde edinebilmeleri için sıklıkla başvurdukları bir yöntemdir (Büyüköztürk, Çakmak, Akgün, Karadeniz ve Demirel, 2008).

\section{Evren ve Örneklem}

Çalışmanın örneklemini Türkiye'de spor iletişimi konusunda en fazla spor sponsorluğu yapan Türk Hava Yolları, Türk Telekom, Anadolu Efes, Garanti Bankası, Türkcell ve Ülker firmalarının yapmış oldukları spor sponsorluğu çalışmaları oluşturmaktadır.

\section{Veri Toplama Araçları}

Betimsel analize tabii tutulan bu çalışmada Türkiye'de en fazla spor sponsorluğu yapan firmaların bu alandaki eğilimlerinin ne yönde olduğunu ortaya koymak ve hangi çalışmalara yer verdiklerini belirlemek hedeflenmiştir. Çalışmada örneklem kapsamındaki firmaların yaptıkları spor sponsorlukları incelenerek veriler toplanmış ve çözümlemesi yapılmıştır.

\section{Verilerin Analizi}

$\mathrm{Bu}$ araştırmada nitel araştırma yöntemlerinden olan betimsel analiz tekniği kullanılmıştır. Betimsel analiz; çeşitli veri toplama teknikleri ile elde edilmiş verilerin daha önceden belirlenmiş temalara göre özetlenmesi ve yorumlanmasını içeren bir nitel veri analiz türüdür. Walcott'un geliştirmiş olduğu analiz yönteminde vurgulandığı gibi, incelenen (spor sponsorluğu çalışmaları) olaylar dolaysız olarak aktarılmaya çalışılmıştır.

\section{Bulgular}

Bu bölümde firmaların yapmış oldukları spor sponsorluğu çalışmalarının analizinden elde edilen bulgular yer almaktadır. Firmaların yapmış oldukları bireysel sponsorluk, takım sponsorlukları ve spor organizasyonları ile sporun geniş kitlelere duyurulup farkındalık yaratma, toplum içerisinde olumlu bir sinerji oluşturma, kısa dönemde geniş hedef kitlelere ulaşma anlamında oldukça olumlu ve avantajlı geri dönüşler sağladığına ilişkin bulgulara aşağıda yer verilmiştir. 


\section{Türk Hava Yolları (THY)}

THY, 2009 yllında 30 milyon dolar olan tanıtım bütçelerini 2010'da 70 milyon dolara, 2012 yllında 100 milyon dolardan 2015 yllında 200 milyon dolara yükselterek pazarlama iletişim çalışmalarının kalbine hem global hem de yerel sponsorlukları yerleştirmiştir. Özellikle global ölçekte büyük sponsorluklarla kendi marka değerini özdeşleştirme çalısmaları da yapan şirket, dünyaca ünlü oyuncuların kullanıldığı reklam çalışmaları, uluslararası organizasyonlarda yer alan reklam filmleri ve farklı ölçeklerdeki pazarlama iletişimi çalışmaları ile global pazarda öncü çalısmalara imza atmaktadır. 2013 yllında 120 milyon dolarlık tanıtım bütçesi 2015 yllında 200 milyon dolarlık tanıtım çalışmaları içerisinde 25 milyon doları spor sponsorluğuna ayıran şirket, spor sponsorluğu alanına önemli yatırımlar yapmaktadır. Sporun bir çok dalında aktif sponsorluk iletişim çalışmalarını gerçekleştiren THY; futboldan basketbola, golften dalışa, Amerikan futbolundan buz hokeyine, atlı sporlardan kriket, koşu ve bisiklet turu organizasyonlarına kadar farklı alanlarda ve ölçeklerde sponsorluk çalışmalarına bütçe ayıran şirket, Türkiye Futbol Federasyonu resmi sponsorluğu adı altında bütçesinden iki sene için 9 milyon TL ayırırken geri kalan bütçenin önemli bir kısmını özellikle yurt dışında sponsorluk yatırımlarına ayrılmaktadır. Türkiye Futbol Federasyonu ile birlikte Milli Takım sponsoru olan THY, basketbolda da Milli Takım ile FIBA Dünya Şampiyonasına sponsorluk yapmakta, ayrıca Euroleague isim sponsorluğu ile de yine Türkiye sınırları dışında önemli bir sponsorluk anlaşmasıyla bilinmektedir.

Spor alanında ciddi sponsorluk çalışmaları bulunan THY, spor takımlarının sponsorluğu konusunda global anlaşmalara imza atmaktadır. Türkiye'de Beşiktaş, Galatasaray, Trabzonspor, Fenerbahçe ve Başakşehir ile sponsorluk çalısmaları bulunan THY, Japonya'da Urawa Reds ve Güney Kore'deki F.C Seul futbol takımlarının sponsorluğunun ardından 2010 yılında FC Barcelona ile gerçekleştirdiği 3 yıllık sponsorluk anlaşması gerçekleştirmiştir. 2015-2016 yıllarında Bosna Hersek'in önde gelen kulüplerinden FK Sarajevo'nun, 2015-2016 sezonunda forma sponsoru olmuş, İngiltere Premier Lig'inin ve dünyanın sayılı futbol kulüplerinden olan Manchester United ile de 3,5 yıllık sponsorluk anlaşmasına imza atmıştır. Anlaşma dahilinde Manchester United'ın resmi sponsoru unvanını alarak, sponsorluk hakkında iletişim çalışmaları yapmaya da hak kazanmıştır. Bu kapsamda kulübün sahası Old Trafford'daki reklam panoları ve internet dahil tüm mecralarında logo kullanım hakkına sahip olmuş, halkla ilişkiler faaliyetlerinde takım oyuncularını kullanma ve yine oyuncuların yer aldığı reklam çekimi faaliyetlerini de gerçekleştirmiştir. Ayrıca, global anlamda yapılan spor iletişim çalışmaları dahilinde Manchester United TV kanalında spot reklam yayınlama hakkına sahip olduğu gibi Manchester United'ı İngiltere dışındaki turnuva ve kamp organizasyonlarına taşımaktadır (Küçükerdoğan, Ekin ve Zeybek, 2011, s. 43).

2010 yılında Barcelona FC ile yapılan sponsorluk anlaşmasına göre THY, Barselona Kulübüne 2,5 sene için 7 milyon 700 bin Euro ödemiş olup yapılan sponsorluk anlaşması Barselona'nın Nou Camp Stadı'nda düzenlenen basın toplantısı ile tüm dünyaya duyurulmuştur. Basın toplantısına giden uçak kulübün renklerine boyanmış, kulübün amblemini de uçağın gövdesine işlemiştir. Uçağın üzerinde ayrıca Barselona'nın "More than a club" sloganı İspanyolca olarak yazılmış ve 6 adet kupa figürü kullanılarak "bir sezonda 6 kupa alan dünya şampiyonu" ifadesine vurgu yapılmıştır. Anlaşmaya göre, uçağın dünyanın hangi noktasına uçtuğuna bakılmaksızın seferlerini bu şekilde yürüteceği de açıklanmıştır. Ayrıca sponsorluk anlaşması kapsamında spor iletişimine de olanak sağlayan farklı mecra kullanımları da yer almaktadır. 2011 yllinda Manchester United ve FC Barcelona arasında FC Barcelona'nın galibiyetiyle sonuçlanan şampiyonlar ligi finali sonrası ilk kez "US Tour" turnuvası kapsamında yapılan karşılaşmanın "Presenting Sponsoru" THY olmuştur. Bu kapsamda, THY’nin tanttım elçilerimden Amerikalı basketbolcu Kobe Bryant tarafindan her iki takımın başarllı oyuncularına kupa verilmiştir.

Sponsorluk anlaşmaları dahilinde kısa vadeli ya da dönemsel ortak çalışmalar da yapıllı iletişim bu anlaşmalar üzerinden kurgulanabilmektedir. Buna örnek olarak THY'nin Atletico Madrid ile tek seferlik yaptığı taşıma anlaşması verilebilir. Anlaşmaya göre, Galatasaray'ın UEFA'daki rakibi Atletico Madrid ile yaptığ maç için bir seferlik taşıma karşılığ1 düşük bir bedel alınmış, karşılığında da THY'nin takımın internet sitesinde ve yaptıkları basın toplantısında reklamı yapılmıştır. (https://www.hurriyet.com.tr) THY ve Ukrayna'nın FC Shakhtar Donetsk takımı, arasında yapılan resmi sponsorluk anlaşması dahilinde de takım formasında sırt reklamı olarak logosunu bulundurmuş ve kulübün kendi sahası Donbass Arena Stadı'ndaki reklam panoları başta olmak üzere internet dahil tüm mecralarında reklam ve logoları ile yer almıştır (https://www.sportspromedia.com).

2013 yılında Almanya Bundesliga takımlarından Borussia Dortmund ile üç y1llık sponsorluk anlaşması imzalamış, filosunda bulunan bir uçağı da takımın renklerine boyamışır. Daha önce Manchester 
United ve Barcelona takımları için de aynı markalama işlemini yapan şirket, burada farklı olarak uçağın kuyruk kısmında sponsor olduğu Borussia Dortmund'un logosunu kullanmıştır. Sponsorluk anlaşması kapsamında takımı uluslararası karşılaşmaları ile hazırlık kamplarına taşıyacak Türk Hava Yolları, Dortmund'un stadinda "lounge" (loca) ile temsil edilme ile birlikte takım ile THY'nin ortak reklamlarda yer alabilme ve sosyal medya işbirliği yer almıştır (https://www.ntvspor.net).

2013 senesi içerisinde İngiltere Premier Lig’in köklü kulüplerinden Aston Villa ile bir senelik resmi sponsorluk sözleşmesi imzalamıştır (Baykan, 2019). bakSponsorluk stratejisinde dünyanın en geniş uçuş ağına sahip hava yolu şirketi olma mesajının verilmesinin yanı sıra, yeni destinasyonların tanıtımı, toplum nezdinde sempati kazanma, marka algısının olumlu yönde pekiştirilmesi ve karşıllıklı kazan- kazan hedefinin yer aldığı THY, Borussia Dortmund işbirliğinde hem kendi markası adına İspanyol ve Premier Lig'den sonra Alman Ligi'nin de önde gelen takımı ile işbirliği yaparak spor iletişimindeki hedef kitlesini genişletmiş ve marka pazarlama hedefleri ile tutarlı bir iletişim çalışmasına imza atmış, benzer şekilde de 2008 yllı itibari ile başlayan Birmingham seferleri ile kurulan ilişkinin devamı olarak Aston Villa'nın köklü kulüp olmasından kaynaklı THY markasının bilinirliğine olumlu katkı sağlayarak yine sefer sayısı artış1, marka bilinirliği ve marka tercihi yönünde bir strateji ile hareket edilmiştir. THY global ölçekli sponsorlukları kapsamında 2016 yllında Fransa'da düzenlenen Avrupa Futbol Şampiyonası UEFA EURO 2016'nın ilk resmi hava yolu ortağı olarak UEFA ile sponsorluk anlaşması imzalayarak hem Türk A Milli Takımı'nı desteklemiş hem de global ölçekte gerçekleștirdiği spor sponsorluk çalışmalarındaki stratejisini desteklemiştir. Benzer şekilde, Latin Amerika pazarındaki payını arttırmak için River Plate ile 2019-2020 sezonundan itibaren 3 yıl boyunca anlaşma yapan marka, bu kapsamda takımın tüm müsabakalarda Türk Hava Yolları logolu forma ile yer alması, stat içi reklamlar, sosyal medya ve reklam çalışmalarını da dahil etmiştir (https://www.hurriyet.com.tr/sporarena).

THY futbol alanındaki sponsorluklarının yanı sıra basketbolda da aktif olarak sponsorluk çalışmalarını yönetmektedir. Türkiye Basketbol Federasyonu ile Aralık 2012 yılına kadar yapılan anlaşma gereği A Milli Basketbol Takımı'nın ana sponsorluğunu üstlenen THY çeşitli sponsorluk anlaşmaları ile basketbola yönelik yatırımlarını da sürdürmektedir. Basketbol Milli Takımlar ana sponsoru THY, A Milli Erkek Basketbol Takımına destek için çektiği "Türkler Uçuyor” isimli reklam filminde de gökyüzünde oynanan maçla dünyanın en yüksek ve en hızlı basket maçını gerçekleştirmiştir (https://www.talpa.org). 2010 yllında Yunanistan'ın basketbol kulüplerinden Maroussi ile 1,5 ylllık bir sponsorluk anlaşması imzalamış ve sponsorluk dâhilinde Maroussi Basketbol Kulübü'nün hem Yunanistan A1 liginde, hem de Avrupa Ligi'ndeki tüm maçlarında giyeceği forma ve eşofmanları ile saha içindeki led panolar, resmi basın açıklamaları, web sitesi ve röportaj panolarında THY logosu kullanım hakkına sahip olmuştur. Ayrıca, THY logosu Maroussínin kendi sahasındaki zeminindeki her iki serbest atış bölgesinde de yer almaktadır (https://www.iha.com.tr).

Şirketin pazarlama hedefleri dahilinde Uzakdoğu bölgesinde tanıtım etkinliği kapsamında Basketbol sporu alanında sponsorluk yatırımı yapılmış ve uçuşların tanıtımı için Japon Basketbol Ligi’ne sponsor olunmuştur. 2010 yilında Euro Cup şampiyonu olan ve aynı zamanda Turkish Airlines Euroleague'de mücadele eden Valencia Basketbol Takımı'na ulaşım sponsorluğu desteği veren Türk Hava Yolları, 2011 yllında da Kavala şehri basketbol takımına destek vermiştir. 2000 yllında düzenlenmeye başlanan Avrupa Basketbol Ligi "EuroLeague" kapsamında 2010'da Paris'teki dörtlü finallerin isim sponsoru olduktan sonra markanın global düzlemdeki gücünü pekiştirip arttırmak amacıyla dünyanın en saygın basketbol organizasyonlarından biri olan EuroLeague'in tarihinde ilk defa isim sponsoru olmuştur. Anlaşma kapsamında; THY, "Euroleague" ve "Euroleague For Life" programı ile birlikte Türkiye ve dünyanın çeşitli yerlerinde sosyal sorumluluk projelerinin gerçekleştirilmesi, oyuncularla reklam filmi çekimi, tüm maçlarda saha zemininde THY logosunun yer alması ve Euroleague ve THY logosundan oluşan yeni bir Euroleague logosunun oluşturulması yer almıştır (https://www.cumhuriyet.com.tr). THY bu anlaşmanın ardından 2020 yılına kadar anlaşmasını uzatmış ve lig 2020 yılına kadar Turkish Airlines Euroleague ismini taşımıştır.

Hem yerel hem uluslararası çapta sponsorluklarını uzun vadeli olarak planlayıp hayata geçiren THY, İngiltere'de düzenlenen "Golf Live 2011" a destek vermiş ve isim sponsorluğunu üstlendikleri "Turkish Airlines Open" aracllığ ile de Tiger Woods, Sergio Garcia, Martin Kaymer ve Rory Mcllroy gibi dünyanın en önemli golf oyuncularını bir araya getirmiştir (https://www.skylife.com). Golf alanında "Turkish Airlines Challenge" ve "Turkish Airlines World Golf Cup" gibi önemli organizasyonlara isim sponsorlukları ile destek vermiştir. THY spor alanındaki iletişimi yönetirken global ölçekli organizasyonlara sponsorluk anlamında destek vermesinin yanı sıra, dünya çapında sporda başarılı olan 
yıldız oyuncuları da marka elçisi olarak kullanmakta, global ölçekte yarışan bireysel sporculara destek vermekte ve yine milyonlarca izleyicinin takip ettiği global organizasyonlarda reklam ve tanıtım faaliyetleri ile yer almaktadır. Ünlü kullanımı kapsamında Kobe Bryant, Lionel Messi ve Caroline Wozniacki gibi ünlü sporcular marka elçisi olarak THY'yi temsil etmiş ve 2013'te dünyada en fazla noktaya uçan hava yolu şirketi olan THY mottosunu "Dünya Daha Büyük Keşfet" olarak değiştirmiş ve bunu Kobe Bryant ve Lionel Messi'nin rol aldığ1 yeni reklam filmiyle duyurmuştur (https://www.aa.com.tr/tr/sirkethaberleri). Amerika ve dünya çapinda milyonlarca izleyiciyi ekran başına kilitleyen Amerikan Ulusal Futbol Ligi (NFL) final maçı olan Super Bowl'a 2016 yılında Batman ve Superman reklamıyla dahil olarak Super Bowl tarihinde yer alan ilk Türk markası olmuş ve 2017'deki Super Bowl sırasında da marka elçisi Morgan Freeman'ın rol aldığı reklam filmleri ile dünya çapındaki marka iletişim çalışmalarını desteklemiştir. THY yolcularının en iyi uçuş deneyimi yaşamalarını amaçlayan bir yaklaşımla Amerika Birleşik Devletleri'nde yaşayan ünlü Türk Cerrah Mehmet Öz ile "İyi uçun iyi hissedin" adlı bir kampanya başlatan THY, bu bölgedeki iletişimini New York'un simge yapılarından 102 katlı Empire State Binası'na çıkma koşusunun ana sponsoru olarak da desteklemiştir (https://www.aa.com.tr/tr/dunya).

Dünya çapında birçok ülkede canlı yayınlanan yüzlerce sporcunun bir araya geldiği Cumhurbaşkanlığ Türkiye Bisiklet Turu, İstanbul Maratonu ve dünyanın ikinci en çok izleyicisi olan spor dalı kriket alanında gerçekleştirilen Cricket Ireland Milli Takım Sponsorluğu, ulusal ve uluslararası alanda yüzlerce madalya sahibi olan Şahika Ercümen'in resmi sponsorluğu ve Finlandiya'nın buz hokeyi takımı IFK Helsinki ile yaptığ1 ana sponsorluk çalışmaları da markanın diğer sponsorluk çalışmaları arasında yer almaktadır (https://www.turkishairlines.com).

2020 yllında global ölçekli pandemi olarak nitelendirilen Covid 19 virüsünün dünyadaki tüm iletişim ve ulaşım ağlarını olumsuz etkilemesi ve büyük bir ekonomik krizi de beraberinde getirmesi ile bir çok firmanın da çalışanların işten çıkarılması, faaliyetlerin durması ve yatııımların azalmasına neden olmuştur. Bu krizden en çok etkilenen sektörlerin başında gelen havacıllk sektöründe faaliyet gösteren THY da global sponsorluklarını azaltarak tasarrufa yönelmiştir. 2019 yllında Kanada futbol kulübü FC Toronto ile imzaladığı sponsorluk anlaşmasını uzatmayan marka, 2017 yılından itibaren sürdürdüğü ve daha önce 2021 yılına kadar anlaşmayı uzattığı İrlanda Kriket Erkekler Takımı sponsorluğundan çekilmiştir (https://www.sozcu.com.tr).

Türk Hava Yollarının spor iletişim çalışmaları incelendiğinde, marka spor sponsorluğu kavramını sadece yerel futbol kulüplerine tek bir alanda destek verme bakış açısı ile sınırlamayan ve farklı spor dallarına yatırım yapan, takım sponsorlukları ile birlikte organizasyonlar ve bireysel sporculara da destek veren, markasının vaadi ile tutarlı, hedefleri ile doğru orantılı, sporun tanıtım amaçlarından faydalanıp uluslararası rekabet içinde davranan ve küresel bakış açısı ile hem yerel hem de uluslararası anlamda kazan kazan yaklaşımı ile hayata geçiren bir marka olarak karşımıza çıkmaktadır. Global ölçekli spor yatırımlarında dünya çapındaki hedef kitlesini öncelikli olarak futbol üzerinden yakalamayı hedefleyen THY, markasını dünyaya entegre etmeye ticari fayda sağlama amacı ile hem marka hem de ülke tanıtım ve pazarlama hedeflerini ortak potada eriterek, ilgili hedef kitlenin dünyanın her bir noktasına THY markası aracilığı ile hem sportif faaliyetler nezdinde hem de fiziksel olarak ulaşmasını hedefliyor diye düşünülebilir. Bunun yanı sıra, sponsorluk yaptığı spor dallarında (örneğin Avrupa Basketbolu) tanınma, farkındalı̆ı̆n artması ve daha geniş kitlelere erişimi; golf ve tenis gibi spor dallarındaki spor iletişim çalsşmaları ile hem izleyici sayısının arttırılması hem de kendi hedefi açısından üst segment hedef kitlesine yönelik iletişimin güçlenmesi (business class yolcuları ya da yüksek statülü sadakat kart sahipleri) açısından katkıda bulunmaktadır. Markanın globalleşme stratejisi, sporun kapsayıcı ve bütünleştirici özelliği ile birlikte dünyanın birçok yerinden farklı sosyo-ekonomik ve kültürel özelliklere sahip kitlelerine ulaşmasını ve hedef kitlesi ile karşlıklı diyaloğa geçmesini sağlamaktadır. Tüm bunların sonucu olarak markanın spor sponsorluğu alanındaki faaliyetleri, spor alanına yapılan yatırımlarla sporun gelişimine etki etmekte, hem kendi marka algısına, hem marka imajina, hem ticari hedeflerin gerçekleşmesi hem de hedef kitlesine yönelik iletişimine olumlu katkı sağlarken, ilgili destinasyonların tanıtımı, uluslararası medyada yer alma, güven oluşturma, sponsor olunan kurum ve organizasyonların imajının transferi, turizm ve ülke tanıtımına katk1, markanın küresel bir oyuncu olarak rakiplerinin içinde vizyonu, güvenilirliği, imajı ve cesareti ile öne geçmesi ve/veya fark yaratması gibi ana pazarlama hedeflerine ulaşmasını sağlamaktadır.

\section{Türk Telekom}

"Türk Sporunun En Büyük Taraftarı" sloganı ile sporseverler ile Türk Telekom markası arasındaki iletişimi güçlendirmek ve Türkiye'yi başarıyla temsil edecek dünya standartlarında sporcuların 
yetiştirilmesine katkıda bulunmak amacıyla yapılan spor yatırımları günden güne artış göstererek hem Türkiye hem de Avrupa'da geniş yankı bulmaktadır.

Türkiye'de ulusal ve uluslararası pek çok spor aktivitesini destekleyen, başta Avea ve TTNET olmak üzere Türk Telekom grup şirketleri, futbol milli takımları, A Milli Voleybol Erkek Takımı, A Milli Voleybol Erkek ve Bayan Genç Takımı, A Milli Voleybol Erkek ve Bayan Yıldız Takımlarının yanı sıra Türkiye Olimpiyat Takımı'nın da alın sponsorluğunu üstlenen Türk Telekom, Avea markası ile Beşiktaş, Fenerbahçe, Galatasaray ve Trabzonspor takımlarına destek vermiştir. Galatasaray Spor Kulübü'nün stadyum sponsoru olarak 10 yılllğına 65 milyon dolarlık yatırım yapan Türk Telekom, Fenerbahçe Spor Kulübü ve Trabzonspor Spor Kulübü sponsorluğu kapsamında da Şükrü Saraçoğlu ve Hüseyin Avni Aker stadyumlarında birer tribünün isim hakkını elde etmiştir (Türk Telekomunikasyon A.Ş Faaliyet Raporu, 2018).

Avea markası ile yapılan sponsorluklar da sponsor firmanın yaptı̆̆ spor iletişimi çerçevesinde Türk futbol taraftarına yönelik de yenilikler yaratma hedefiyle gerçekleştirilmiştir. Uluslararası boyutta FC Barcelona'nın 2012-2013 sezonu sonuna kadar "Resmi Telekomünikasyon İş Ortakllğı" ile Avea kullanıcıları FC Barcelona'nın Camp Nou Stadyumu'nda oynayacağı her maça ve FCB Müzesi gezisi için hediye bilet kazanma şansı elde etmektedir. Ayrıca, Avea kullanıcılarına, FCB markalı ürünlere, mobil içeriklere, tarifelere ve diğer GSM ürünlerine ulaşma şansı sunmuştur.

Toplum yararına yapılan iletişim çalışmaları dahilinde ülkede spor bilincini ve sevgisini artırmaya yönelik faaliyetler kapsamında da olimpiyatlardaki başarıyı artırmak, spor ve sporcuları tanıtmak ve gençlerin kişisel gelişimine katkıda bulunmak amacıyla da Türkiye Olimpiyat Takımı'nın alın sponsorluğunu üstlenmiştir. Ayrıca, futbolun ve fair play olgusunun yaygınlaşması ve yerleşmesi amacıyla UEFA tarafından öncelikli programlar arasında gösterilen Herkes İçin Futbol Programı'nda Kurumlararası Futbol Turnuvası'nın ana sponsoru olarak da faaliyet göstermektedir.

Dünyanın en değerli kulübü olarak adlandırılan Manchester United ile Türk Telekom Grubu arasında yapılan anlaşma doğrultusunda, Manchester United'ın mobil hakları, online oyun hakları, sosyal medya projeleri, spor okullarına dair hakları ile satış ve ağırlama haklarının kullanımı 3 seneliğine Türk Telekom Grubu'na verilmiştir. THY- FC Barcelona arasında gerçekleştirilen sponsorluk anlaşmasına benzer şekilde takımın ünlü futbolcularının Türk Telekom reklamlarında oynaması da sponsorluk anlaşmasına dahil edilmiştir. Çeşitli etkinliklerin yapılacağı anlaşmada Manchester'ın aldığı Premier Lig Şampiyonluk Kupası'nın İstanbul'da sergilenmesi de yer almaktadır. Aynı gruba ait şirketlerden Sobee'nin online futbol oyunu olan "I Can Football" isimli oyunun ikinci versiyonunda da Manchester United'ın lisanslı içerikleri yer almaktadır (https://www.marketingturkiye.com.tr).

2003-2013 yılları arasında spor yatırımları ve sponsorluklara yaklaşık 350 milyon lira harcadığını belirten marka, 2013 senesinden 2019'a kadar öncelikli olarak futbol olmak üzere farklı spor dallarına toplam 150 milyon liralık yatırım yapacağını belirtmiş, ancak; 2014 yılında sponsorluk faaliyetlerinin yönünü değiştirmiştir. Markadan yapılan açıklamada, spor yaptırımlarının alt yapı projeleri, genç sporcu yetiştirme programları ve ülke sporunun geleceğine yönelik çalışmalarla devam edeceği belirtilerek, Fenerbahçe, Galatasaray ve Trabzonspor forma sponsorluklarını yenilememiş ama stat isim sponsorluğuna devam etmiştir (https://www.aa.com.tr/tr/spor/turk).

Özellikle 2004 yılı itibariyle Türkiye'nin spor altyapısına yaptı̆̆ binlerce sporcunun yetişmesine katk1 sağlayan Türk Telekom, yurt genelinde adını taşıyan amatör spor kulüpleri ile birlikte yaklaşık binlerce genç sporcuyu desteklemiştir. Spor okulları için milyon TL'lik yatırımlar yapan marka, Türk Telekom Spor Okulları ile birlikte binlerce öğrenciye ulaşmakta, altyapı destekleri ile on binlerce sporcunun yetişmesine olanak sağlamakta, amatör kategorilerdeki spor kulüpleri ve oyuncuları da desteklemektedirler. Türkiye'nin birçok yerine tesisler inşa ederek herkesin spor yapma imkanına kavuşmasına yönelik spor yatırımlarını yapan marka hem yaptığı sponsorluk çalışmaları hem de sosyal sorumluluğu ön planda tutan iletişim çalışmaları ile Türkiye'deki sporun gelişimine katkıda bulunmaktadır.

\section{Anadolu Efes}

Spor alanına yaptığı yatırımlar ile spor iletişim ve spor sponsorluklarını hem Türkiye hem de uluslararası çapta genişleten şirketlerden biri olan Anadolu Efes, spor takımlarından federasyonlara, yerel spor organizasyonlarından uluslararası çapta organizasyonlara kadar sporun her alanında aktif olarak faaliyet göstermekte ve spora destek vermektedir. 2013 yılı öncesi spor iletişiminde öncü bir marka olarak Efes Pilsen markası ile diğer birçok markaya yol gösterici faaliyetlerde bulunan Anadolu Efes’in resmi 
internet sitesinden alınan bilgiye göre, kurum spor alanında gerçekleştirdiği tüm sponsorluk faaliyetlerini sosyal sorumluluk projesi olarak ele almakta ve iletişimini bu doğrultuda yönlendirmektedir. Buna göre, Anadolu Efes, spordaki ilerlemenin toplumsal gelissime katkısını göz önüne alarak Türk sporunun gelişmesi ve dünya çapında başarılı olması adına uzun vadeli yatırımlar gerçekleştirmektedir.

1976 yllında kurulan Efes Pilsen Spor Kulübü ile basketbol dalını sahiplenen Anadolu Efes, 2008 yllından bu yana en önemli profesyonel basketbol organizasyonlarından biri olma özelliğini taşıyan Euroleague Basketball'ın sponsorluğunu yapmaktadır. Ayrıca, yine uluslararası çapta geniş yankı sağlayan Uluslararası Basketbol Federasyonu (FIBA) 2010’un resmi etkinlik sponsorluğunu da üstlenen Efes Pilsen takım sponsorluğu konusunda da aktif bir görev üstlenmiştir. 2011 yllında yürürlüğe giren "Tütün Mamulleri ve Alkollü İçkilerin Satışa ve Sunumuna İlişkin Usul ve Esaslar Hakkında Yönetmelik" e kadar futbol alanında ciddi yatırımlar gerçekleştiren Efes Pilsen, 2002 yllı itibari ile Türk Milli Futbol Takımları Ana Sponsoru, Galatasaray, Beşiktaş ve Fenerbahçe'nin resmi sponsoru ve birçok Anadolu Kulübü’nün de sponsorluğunu yapmıştır. Antalya'da devre arasında düzenlenen "Efes Pilsen Cup" ile izleyicilere dünya kulüplerinin maçlarını izleme olanağı tanımıştır. Ayrıca, isim sporluğunu yaptığ1 Türkiye Futbol Federasyonu tarafindan organize edilen Efes Pilsen Futsal Ligi ile de başarılı olan takım Türkiye'yi UEFA Avrupa Futsal Kupası'nda temsil etme hakkını elde etmiştir. Yönetmeliğin kabulü ile birlikte spor alanındaki sponsorluk çalışmalarına son vermiş ve logosu sponsorlar arasından çıkarılmıştır. Ayrıca kabul edilen yönetmelik doğrultusunda Efes Pilsen Basketbol Takımı'nın ismi de "Anadolu Efes" olarak değiştirilmiştir (https://wwww.tff.org, https://www.cnnturk.com).

Milli Olimpiyat Komitesinin de sponsorluğunu yapan Anadolu Efes, spor dalındaki destekleme faaliyetlerini sosyal sorumluluk amaçlı projeler ile de zenginleştirip topluma fayda sağlayacak çıktılar elde etmeye çalışmıştır. Türk basketbolunun gelişimi için bir sosyal sorumluluk projesi olarak hayata geçirilen "Anadolu Efes İle İlk Adım Basketbol Okulları" ile birlikte 2004 yilından itibaren birçok ilde binlerce genci basketbol ile tanıştırmıştır (Cevahircioğlu, 2007: 91). 2006 yllından itibaren de basketbol okullarındaki başarılı gençlerin katılımıyla düzenlenen "Anadolu Efes İle İlk Adım Yaz Kampı" dahil edilmiştir. Bu kamplarda, hem başarılı gençlerin ödüllendirilmesi hem de yurt çapına yayılan okullardaki öğrencilerin Anadolu Efes Spor Kulübü çatısı altında toplanarak kaynaşmalarının sağlanması hedeflenmektedir. Bunun yanı sıra, futbol yatırımlarını arttıran kurum, futbol ve Türk Milli Takımı ile ilgili tüm bilgilerin yer aldığ1 www.millifutboltarihi.com sitesine destek vererek sporseverlere yönelik hizmetlerini sponsorluk dış1 projelerde de göstermeye devam etmektedir (http://halklailiskiler.com.tr).

Efes Pilsen, spor iletişimi planlaması içinde yer alan spor iletişim çalışmalarında hem sponsorluğu hem taraftar iletişimini hem de sosyal sorumluluk kampanyalarını bir arada kullanmaktadır. Tüm iletişim çalışmalarını hem çizgi altı hem de çizgi üstü reklamcılık öğeleri ile birlikte kullanan kurum, direkt iletişim ve dijital alandaki iletişim mecralarından da sıkça faydalanmaktadır. Futbol sponsorluklarını hem federasyon hem de takım sponsorluğu türlerinde değerlendirmekle birlikte iletişimini logo kullanımlarının yanı sıra sosyal mecralarda da aktif olarak yönetmektedir. Basketbol dalında ise Anadolu Efes takımı ile mücadele eden kurum, basketbol alanındaki yatırımlarını genişletirken iletişimini de tüm pazarlama karması ve halkla ilişkiler öğeleri ile desteklemektedir. Eğlence odaklı etkinliklerin ve sadakat programlarının basketbol sporu içerisinde bir eğlence platformu oluşturduğu fikriyle iletişim yapan Efes'in bu etkinlikler ve programlar ile basketbol sporuna yönelik ilgiyi arttırmaktadır. Karşılaşmalar öncesindeki aktiviteler, maç günü etkinlikler, periyotlar arasındaki oyun ve gösteriler, Efes kızlarının gösterileri, Efes davul takımı, maç öncesi Efes makyaj ekibinin taraftarlara yönelik etkileşim faaliyetleri vb. hem taraftar ile kurum arasındaki iletişimi hem de basketbola ilgiyi yükseltmektedir. Takım aktiviteleri çerçevesinde düzenlenen yemekler, yarışmalar, sosyal mecralarda mesajlaşma, antrenman katılımı vb. gibi takım ile taraftar arasındaki iletişimi güçlendirecek etkinlikler de spor iletişimi çerçevesinde yapılan iletişim faaliyetleri arasındadır. Basketbol takımı kurumsal sitesi de kampanyalar, fikstür, maç puan durumu, haberler, Efes Fan Store ve basın yansımaları hakkında haberler ile sosyal sorumluluk projeleri hakkında ziyaretçilere bilgi vermekte ve çevrim içi ürün satışı da yapmaktadır. Kurumsal blog aracıllı̆̆ ile de hedef kitle ile direkt iletişim sağlamakta, kampanyalar, yenilikler ve sosyal sorumluluk projeleri ile ilgili güncel bilgiler vermektedir.

Alkollü içeceklerin reklam yapmalarına ilişkin yapılan yasal düzenleme ile alkollü içecek firmaları çocuklara ve gençlere yönelik iletişim faaliyetlerini durdurmuş ve Efes Pilsen tarafindan gerçekleştirilen sponsorluk ve tanıtım faaliyetleri, reklam çalışmaları, web sayfası vb. gibi tüm pazarlama iletişim faaliyetleri durdurulmuştur. Marka, Efes Pilsen adı ile anılan ve Türkiye'yi uluslararası arenada temsil eden ve Koraç Kupası gibi basketbol sporunun en önemli kupalarından birini getiren spor takımının ismini Anadolu Efes 
olarak değiştirmiş, kurumsal iletişim faaliyetlerine ağırlık vermiş ve markalarını "karanlık pazar" kuralları doğrultusunda konumlamıştır. Anadolu Efes çatısında yer alan markalar, karanlık pazar kuralları doğrultusunda markayı çağrıştıracak "sosyal marka" adı altında farklı isimlerle marka iletişimi yapmaya çalışırken, Anadolu Efes markası ile Euroleague sponsorluğu ve basketbol takımının spor iletişim faaliyetlerine devam edilmiştir. Euroleague sponsorluğu kapsamında, saha içi reklam çalışmaları, sosyal medya kanallarının kullanımı, taraftarlar ve kanaat önderleri ile maçı yerinden izleme, "Efes Kızları" adı altında faaliyet gösteren dans ekipleri ile maç aralarındaki şovlar, sporcularla taraftar buluşmaları, fan zone aktiviteleri, halkla ilişkiler çalışmaları, vb. gerçekleştirilmektedir.

10 Temmuz 2019 tarihindeki pazarlamasyon.com sitesinden alınan bilgilere göre; 2018-2019 sezonunda yeni logosu ve basketbolun yalnızca bir spor değil bir yaşam biçimi olduğunun altını çizen \#BenimYerimBurası iletişim stratejisi ile sosyal medya platformlarında aktif bir iletişim yapan kulüp, takipçi sayısını \%32, etkileşim sayısını da \%101 arttırmıştır. Anadolu Efes Spor Kulübü Mobil Uygulaması'nda \%60 kullanım artışı elde edilirken, Anadolu Efes'in resmi internet sitesi www.anadoluefessk.org'un ziyaret trafiği de yine bir önceki sezona göre \%72 artmıştır. Bir önceki sezona göre tribün doluluğunu \%125 artıran Anadolu Efes, Turkish Airlines EuroLeague ve Tahincioğlu Basketbol Süper Ligi'nde ev sahibi olduğu pek çok maçı kapalı gişe oynamışır. 2019-2020 sezonunda hem iptal edilen Turkish Airlines Euroleague hem de ING Basketbol Süper Ligiłi lider olarak tamamlayan Anadoluefes Spor Kulübü, Euroleague ve Eurocup'ta yer alan kulüplerin sezon boyunca gerçekleştirdikleri pazarlama ve iletişim faaliyetlerinin yanı sıra gelecek dönem stratejilerinin değerlendirildiği Euroleague Devotion Pazarlama Ödülleri’nde altın ödül kazanmıştır. Türk sporunu ileriye götürmek, Türk basketbolunun marka değerini ve bilinirliğini arttırmak ve Avrupa sahalarında ülkemizi başarı ile temsil ederek basketbolu tüm gençlere sevdirmek gibi temel bir amacı olan kulüp iletişim faaliyetlerinde taraftar aidiyet duygusunu en önde tutmuştur. Ayrıca, Covid 19 sürecinde evde olan hedef kitlesine yönelik 360 derecelik bir pazarlama iletişim stratejisi ile ulaşmıştır. Sosyal fayda, taraftarla bütünleşme, kombine sahipleri ile ilişkiler ve partner markalar ile ilişkiler gibi unsurların ana başlık olarak ele alındığı iletişim stratejisiyle; Covid 19 ile ilgili bilgilendirici iletişim çalısmalarıla evde oturan hedef kitlenin eğlenmesine, iyi hissetmesine ve toplumsal bilincin gelişmesine katkı sağlanmıştır. "Taraftarlarla bütünleşme” başlığı altında \#Unutulmayacaksezon iletişim kampanyası ile salgından dolayı tamamlanamayan sezonda taraftar iletişimine yönelik; taraftarların tüm duygularını ve anılarını paylaştığı bir dijital mecra oluşturup taraftarların etkileşimi sağlanırken, tüm kulüp sponsorları ile yapılan ödüllü yarışmalar, dijital taraftar buluşmaları, evde spor etkinlikleri, e-spor turnuvaları, anketler, oyuncu vlogları gibi çalışmalar yapılırken, sosyal medya mecraları bir yayın platformu gibi çalışıışıtır. Procter\&Gamble çatısı altındaki "Old Spice" markası ile Bil Grup markalarından Bilcee markası ile yeni sponsorluklara imza atılan bu olağan üstü dönemde, ilk kez dijital imza ve dijital basın toplantısı ile sponsorluk anlaşması yapılmıştır. Yapılan pazarlama faaliyetleri sonucunda; partner markaların neredeyse tamamı ile yeni iletişim firsatları yaratılırken, takım taraftar buluşmaları yüzde 1050 artış göstermiş, A Takım oyuncularının tamamı dijital platformlarda taraftarlarla buluşturulmuş ve 200.000 den fazla taraftarla etkileşime geçilmiştir (https://www.hurriyet.com.tr/sporarena). Euroleague sponsorluğu ile hem paydaşlar, hem taraftar hem de spor camiası içerisinde fark yaratan çalışmalara imza atan marka, Türk basketboluna yeni yıldızlar kazandırmak ve Türkiye'de basketbol sevgisini daha geniş kitlelere yaymak adına ANKA Spor organizasyonu ile İstanbul'da Basketbol Okulları açarak genç sporculara hem basketbol eğitimi alıp, takım olma bilinci kazanarak sporcu disiplinine sahip olmalarını ve özgüven kazanmalarına olanak sağlamıştır. Ayrıca, basketbolda profesyonel sporcu olmak isteyen yetenekli gençlere eğitim ve lisans imkanı sağlayarak sporcu gelişimine de zemin hazırlamaya devam etmektedir.

\section{Garanti Bankas1}

Futbol, basketbol ve binicilik gibi spor dallarında sponsorluk çalışmalarını gerçekleştiren Garanti Bankas1, hem sponsorluk hem de sosyal sorumluk projelerinde de faaliyet göstermektedir. Türkiye Basketbol A Milli Takımı Bayan ve Erkekler'in ana sponsoru olan Garanti Bankası, sponsorluk kapsamında Anadolu'daki gençlere basketbolu sevdirmek ve öğretmek amacı ile "12 Dev Adam Basketbol Okulları" projesine destek vermekte, uluslararası çapta da NBA'in Türkiye'deki etkinliklerinin de ana sponsorluğunu üstlenmektedir. Faaliyetlerine başladığ günden bugüne on binlerce çocuğu basketbol sporu ile tanıştıran 12 Dev Adam Basketbol Okulları, 2018 yllı itibariyle yeni formattyla faaliyetlerine devam etmektedir. Nitelikli basketbol eğitimiyle çocukların gelişimlerine katkı sağlamak ve alt yap1 milli takımlarına oyuncu havuzu oluşturması hedeflenen 12 DABO'da 9-12 yaş aralığındaki kız ve erkek sporcular eğitim görmektedirler. 12 DABO'da eğitim görecek sporcular ise Alt Yap1 Milli Takım 
antrenörleri tarafindan yapılan taramalarla belirlenmektedir. (https://www.tbf.org.tr) Spor sponsorluğunun kurumsal hedeflerinin başında gelen "kurum imaj1" ve imaj transferi amac1 Garanti Bankas1 sponsorluğunda da ortaya çıkmaktadır. Basketbolun yapısı gereği disiplin, takım çalışması ve güven gibi unsurlar kurumun benimsediği değerler ile birebir örtüşmektedir. Ayrıca yapmış olduğu iletişimde erkek basketbol oyuncularını "12 Dev Adam" olarak bayan basketbol oyuncuları ise " Potanın Perileri” olarak konumlayarak, bu isimleri markalaştırmış ve iletişimini bu markalar üzerinden gerçekleştirmiştir (https://www.garantibbva.com.tr).

Spor iletişimi kapsamında oyuncuların motivasyonunu arttırmak için de çeşitli iletişsim kampanyaları yapılmaktadır. Bu kampanyalar hem federasyon hem de sponsor firmaların birlikte yürüttükleri iletişim stratejileri ile uygulanmakta ve böylece hem ilgili spor alanına hem de sponsor firmanın hedeflerine ulașması konusunda olumlu yönden katkı sağlamaktadır. Garanti Bankası tarafından 2001 yılında hayata geçirilen "12 Dev Adam" spor iletişim projesinin Türk basketbolu ve Türk sporunda pazarlama iletişimi, spor sponsorluğu ve halkla ilişkiler anlamında önemli katkılar sağladığ1 gözlemlenmiştir. 32. Avrupa Basketbol Şampiyonası kapsamında şampiyonaya olan ilgiyi artırmak ve salonlara daha fazla izleyici çekip Türk basketboluna destek vermek amacı ile halkla ilişkiler araçları da etkin bir şekilde kullanılmıştır. Öncelikle 12 oyuncu "12 Dev Adam" sloganı ile konumlandırılarak şampiyonayı bu slogan ile özdeşleștirme çabası içine girilmiş ve oldukça başarılı bir çalışma yapılmıştır. Şampiyona Slogan ile birlikte özellikle genç hedef kitlenin oldukça yakından takip ettiği müzik grubu Athena da Milli Takım için özel olarak şarkı hazırlamıştır. Bu şarkı grup tarafindan birebir karşılaşmalara gidilerek taraftarlarla birlikte söylenmiş, bununla birlikte etkisin arttırılması için Garanti Bankası santralinde de kullanılmıştır. Farklı iletişim kanalları ile hedef kitleye yönlendirilen ve marş haline gelen şarkı herkesin dilinde yer etmiştir. “Türkiye'nin Onuru Garanti'nin Gururu” konsepti ile şampiyonaya özel hazırlanan reklam filmi de kampanyanın önemli iletişim araçlarından biri olmuştur. Ayrıca Garanti Bankası web sitesi de iletişim için etkin bir platform olarak kullanılmıştır. İlgili sitede takım hakkında detaylı bilgiler, fikstür, oyuncular, reklam filmi, ekran koruyucuları ve marş gibi detaylı bilgiye yer verilmiştir. Kampanya sonrası bile her ne kadar takım oyuncuları değişiklik gösterse de 2001 yılından bu yana A Milli Basketbol takımı 12 Dev Adam olarak anılmaya devam etmiştir (Gürel, 2006, ss. 185-190).

Takım arkadaşlığı, azim, disiplin, kendini adamışlık, güven ve çok çalışmanın yanı sıra başarılı sonuçlarla dönen takımlarımızın bu başarılarında federasyon ve sponsor firmaların payı yüksektir. 2010 FIBA Dünya Basketbol Şampiyonası’nda gümüş madalya kazanan “12 Dev Adam”a destek olmak adına sponsor firma Garanti Bankası'ndan oluşturulan ve farklı iletişim disiplinlerinin bir arada kullanıldığ1 reklam ve tanıtım kampanyası dahilinde sosyal medya, kitle iletişim araçları, basın iletişimi, resmi internet sitesi, etkinlik, pazarlama iletişimi ve halkla ilişkilerin unsurlarından yararlanılmıştır. Reklam ve tanıtım kampanyası kapsamında motivasyonu yükseltmek ve milli takıma desteği vurgulamak adına reklam kampanyası yapılmıs, reklam filminde saha ortasında bir orkestra kurularak oyuncular "12 Dev Adam" marşını söyleyerek taraftarlar ile bütünleşmişlerdir (https://www.hurriyet.com.tr/12-dev-adam). Dijital ortamda 12 Dev Adam resmi Internet sitesi "www.12devadam.com" tüm iletişim yapılırken, tüm güncel haberler Facebook ve Twitter hesapları üzerinden taraftarlar ile paylaşılmıştır. Facebook üzerinde düzenlenen ve en çok pas atan taraftarın ödüllendirildiği "1 Milyon Pas" yarışmasında 1 milyona yakın destek pas atışı gerçekleştirilmiştir. Özel olarak çekilen reklam filmleri Iphone ile etkileşimli olarak kurgulanmış, "Garanti 12 Dev Adam" uygulaması yaratılmıştır (https://sosyalmedya.co). Karşılaşmaların yapıldığı salonlarda kurulan ve interaktif uygulamalara zemin yaratan standlar taraftar ile yakın iletişimi sağlarken maç arasında "12 Dev Adam Marşı" nı da seslendiren Athena grubunun konseri ile taraftarın rekabet ruhuna dokunularak deneyim yaşatılmıştır (https://shgm.gsb.gov.tr/). "Garanti Basketbol Karnavalı" kapsamında Dünya Basketbol Şampiyonası'nın maskotu "Bascat" eşliğinde İstanbul ve Ankara'da çeşitli etkinlikler gerçekleştirilmiş, Şampiyonada Dünya ikincisi olan Milli Takım’a teşekkür için sponsor kurumun binası $12 \mathrm{Dev}$ Adam posteriyle giydirilmiştir (https://www.hurriyet.com.tr/istanbulpark).

12 Dev Adam iletişim projesi yalnızca takım sponsorluğu olarak kalmamıs, basketbol sporunun gelişimi ve iyileştirilmesi adına da çeşitli yatırımlar gerçekleştirilmiştir. 2002 yılında başlayan "12 Dev Adam Basketbol Okulları" projesinde ise topluma değer katma amacıyla hareket edilmekte, basketbol sevgisini Türkiye çapında yayarak, geleceğin sporcularını yetiştirmek hedeflenmiştir. Geleceğin basketbol oyuncularının yetişmesi amaciyla sponsor firma Garanti Bankası ve Türkiye Basketbol Federasyonu işbirliği ile basketbol eğitimleri verilmiş, 12 Dev Adam spor okulları açllmış, yine aynı isimle Türkiye'nin 
farklı bölgelerinden gelen genç basketbol oyuncuların karşılaşmalarının yer aldığı festivaller gerçekleştirilmiş, genç oyunculara yönelik turnuva ve çeşitli spor kampları düzenlenmiştir.

Basketbolu sevdirmek ve potansiyel genç oyuncuları keşfedip basketbol oynamaya teşvik etmek adına çeşitli organizasyonlar da yapan Garanti, Amerikan Ulusal Basketbol Birliği (NBA) ile de işbirliğine girerek hem sponsorluk alanını uluslararası çapta genişletmekte hem de sporcuya yatırım yapmaktadır. NBA Skills Challenge Basketbol Yarışması'na sponsor olarak basketbola meraklı genç oyuncuları, yeteneklerini göstermeleri adına çeşitli mecralarda yarışmaya davet etmiştir. Yapılan iletişim kapsamında 13-18 yaş arası katılımcılar, 2-3 dakikalık videolarını etkinliğin resmi web sitesi "nba-garanti.com" a yükleyip, yaptıkları sokak çekimlerini de siteye yüklemişlerdir. İzleyiciler tarafından oylanan ve NBA uzmanlarından oluşan jüri heyeti tarafindan da puan verilen performanslar arasından seçilen finalistler NBA işbirliği ile NBA Gençlik Kampına katılma şansı yakalamışlardır (https://wwww.hurriyet.com.tr/nba-skills). Bunun yanı sıra NBA'in Eğlence Tırı “NBA Jam Van”i Avrupa Turu kapsamında İstanbul'a getirip çeşitli yarışma ve etkinlikler ile her yaştan basketbol severe NBA'in heyecanını yaşatmaya gayret etmiştir (https://www.hurriyet.com.tr/nba-jam).

Basketbolun yanı sıra binicilik sporuna de destek veren Garanti Bankası, Türkiye Binicilik Federasyonu'nun resmi sponsoru olmuştur. Futbola da ciddi sponsorluk yatırımı yapan kurum Türkiye "A Milli Erkek Futbol Takımı" resmi sponsorluğu üstlenip ülke çapında geniş bir kampanyaya imza atmıştır. Plaj futbolu ve U17 Milli Takımlar Avrupa Futbol Şampiyonası gibi profesyonel sporcuların gelişimine destek veren organizasyonlara da sponsorluk gerçekleştiren kurum, spor ve sponsorluk iletişimi kapsamında oldukça aktif rol üstlenmektedir.

\section{Turkcell}

Turkcell spor alanına yapmış olduğu yatırımlar ile Türkiye'nin önde gelen sponsor şirketlerinden biri olmuştur. Kurulduğu günden itibaren yaklaşık 25 spor branşında, toplam 600 milyon TL'nin üzerinde maddi destekle 40.000 den fazla sporcunun yanında olan Turkcell 2002 yllında Milli Takım "Resmi İletişim Sponsoru" olarak futbol branşındaki sponsorluk faaliyetlerine başlamış, 2005 yllı itibariyle "Milli Takımlar Ana Sponsorluğu" nu üstlenmiştir. 2003 yllından 2009-2010 sezon sonuna kadar Süper Lig'de mücadele eden Anadolu takımlarına destek veren kurum, 11 Ağustos 2005 tarihinde Türkiye Profesyonel Futbol Ligine ismini vermiş, 2010 yllına kadar lig "Turkcell Super Lig" olarak anılmışıtır (https://www.turkcell.com.tr/tr/hakkimizda). Turkcell, taraftarın dilinde markasıly birlikte anılan futbol ligi için özel bir logo hazırlamıs, bu logo Turkcell Süper Lig’le ilgili tüm doküman, reklam ve iletişim çalışmaları ile birlikte 50'nci Yıl boyunca tüm maçlardan önce yapılan seremonilerde de kullanılmıştır (https://www.yenicaggazetesi.com). 2008/2009 sezonu için, 50. Yll’a özel olarak, Euro 2008'te yoğun ilgi gören "Goller Cepte" servisini indirimli kombine üyelik kampanyasıyla uygulamıştır. Ayrıca hoşgörülü ve centilmen bir futbol için de Turkcell Fair Play Ligi organize edilmiştir. 2002'de "Resmi İletişim Sponsoru", 2006 itibari ile de "Ana Sponsor" olarak Basketbol Erkek Milli Takımların ana sponsorluğunu da üstlenen Turkcell, Türkiye Profesyonel Futbol Ligi'nin isim hakkının Süper Toto tarafindan alınması ile birlikte bireysel sporcuların sponsorluğuna ve futbol dışında yüzme ve tenis gibi spor dallarında yaptığı sponsorluk çalışmalarına ağırlık vermektedir (Turkcell Faaliyet Raporu, 2018). Türkiye Yelken Federasyonu'nun 1 yl süresince ana sponsoru olan Turkcell, atletizm ve yüzme gibi Türkiye'nin Olimpiyat hedefinde en önemli yeri tutan iki branşa da uzun yıllardır yatırım yapmaktadır. Ayrıca, Gençlik ve Spor Bakanlığı'nın himayesinde 56 milyon TL ile Türkiye'nin ilk ve en büyük kaynağa sahip Olimpik sporları projesini hayata geçirmiştir (https:/ /www.bik.gov.tr).

Bireysel dallarda Türk sporunu daha ileriye taşıyacak ve Türkiye'yi uluslararası platformlarda başarıyla temsil edecek gençleri yetiştirme sürecine destek veren kurum sporda sosyal sorumluluğun altının çizildiği projeler ile çeşitli spor dallarında aktif olarak projeler ortaya koymakta ve engelli sporculara yönelik "Görme Engelli Bisiklet" projesi ile de olimpiyatlara sporcu hazırlamaktadır. "Görme Engelli Spor Federasyonu’nun ana sponsoru olan marka, 2013 yllında Türkiye Futbol Federasyonu ve Türkiye Görme Engelliler Spor Federasyonu ile yaptıkları işbirliği çerçevesinde "Turkcell Sesi Görenler Ligi" ni kurarak Avrupa da ilk kez bir engelli futbol liginin isim sponsoru olmuştur (https://www.turkcell.com.tr/sosyaldestek). Ayrıca, Ampute Futbol Milli Takımı ve Görme Engelliler Milli Takımı'na da sponsor olan marka ve Rio 2016 Paralimpik Oyunları'na giden yolda Milli Takıma büyük destek sağlamıştır (http://www.gesf.org.tr).

Yaptığı sponsorluk çalışmalarını etkinlik ağırlıklı organizasyonlar ile destekleyen Turkcell, kitle iletişim araçları ile birlikte sosyal medyayı sıklıkla kullanmaktadır. Yazılı ve görsel mecralarda sponsoru olduğu 
etkinlikleri ve başarıları basın toplantısı, röportaj, basın bülten paylaşımı, video ve reklam aracıllı̆ı ile duyuran Turkcell, Turkcellblog, Twitter ve Facebook hesaplarını da aktif olarak kullanmaktadır. 2012 Avrupa Şampiyonası elemeleri Türkiye - Avusturya maçı öncesi Twitter üzerinden iletişim yapan Turkcell, "Sloganını Tweetle Millileri Tribünde Destekle" adı altında "tweet slogan" yarışması düzenlemiş, sloganlarda "Milli Takım”, “Ay Yıldızlılar”, "Türkiye” gibi Milli Takım’ı çağrıştıracak kelimeleri kullanmış ve slogan sonuna@ Turkcell koyup paylaşmışlardır. Ödül olarak kazanan bir çift maçı yerinde izleyerek Milli Takım'a destek olmuştur. Twitter üzerinden yapılan bir diğer iletişim çalışması ise, 2012 Avrupa Şampiyonası elemeleri A grubunda oynanan Avusturya Türkiye maçını "www.twittertribunu.com" adresinden canlı yayınlamasıdır. Siteye Twitter hesabıyla girenler maç hakkındaki yorumlarını Twitter üzerinden “\#TurkcellTribünü” etiketi ile paylaşmıslardır.

Saha aktiviteleri ile de sponsorluk çalışmalarını destekleyen Turkcell, Bağdat Caddesinde kurulan TíM (Turkcell İletişim Merkezi) mağaza önünde kurulan alanda maçı internetten izlemek isteyenlere bilgi vermiş, etkinliğe renk katmak ve ilgiyi çekmek adına da taraftarlara "şaşırtan gözlükle gol atma", "langırt" ve "helyum gazıyla marş söyleme" gibi oyunlar oynatmıştır. Taraftara yönelik aktivitelerini saha içerisinde de aktif olarak sürdüren kurum, Avrupa şampiyonası öncesi, Basketbol Milli Takımı'na verdiği ana sponsorluk desteğini 2015 yılına kadar yenilemiş ve Takım'a Litvanya'daki Avrupa Şampiyonası boyunca tribünlerden destek veren 15 kişiden oluşan "Turkcell Coşsusu” adlı davul grubunu oluşturmuştur (https://www.milliyet.com.tr). Ayrıca, ana sponsoru olduğu A Milli Futbol Takımı'nın Avrupa Şampiyonası Eleme Grubunda Almanya ile İstanbul'da yapıldığı karşılaşma öncesinde NTV işbirliği ile 50 bin kırmızı beyaz atkı taraftarlara dağıtılarak, tüm tribünler kırmızı beyaza boyanmış ve bu görsel hareketle Milli Takım'a destek verilmiştir (https://www.fotomac.com.tr).

\section{Ülker}

Yıldız Holding, bünyesinde bulundurduğu farklı markalarla hedef kitlesi ile arasındaki duygusal bağ1 güçlendirmek, markalarının algısını pekiştirmek ve korumak amacı ile spor sponsorluğu konusunda Türkiye'de geniş çaplı yatırımlarda bulunmaktadır. Kulüp ve federasyon sponsorlukları ile birlikte futbol ve basketbol branşlarında sponsorluk çalışmaları yapan kurum, spor organizasyonları ve spor odaklı sosyal sorumluluk projelerine de sporun gelişimi ve çocuklar ile gençlerin spor yapabilmeleri adına faaliyette bulunmaktadır. 2005 yılı itibariyle futbol branşında Ülker markası ile Milli Takımlar sponsorluğunu yapan kurum, Beşiktaş, Bursaspor, Fenerbahçe, Galatasaray ve Trabzonspor'a sponsor olarak destek vermekte, ayrıca basketbol branşında da Fenerbahçe Basketbol Şubesi ve Ülkerspor'un birleşmesinden doğan Fenerbahçe Ülker'i desteklemektedir. Basketbol branşında 2011 yllına kadar ylllk F.Bahçe'ye 7 milyon, Galatasaray'a 5, Beşiktaş'a 4.5 milyon Euro veren Ülker, 5 yılda toplam 77.5 milyon Euro sponsorluk harcamasına yatırım yapmaktadır (https://www.hurriyet.com.tr/ekonomi).

Takım sponsorluk anlaşmalarında, forma sırtında logo kullanımının yanı sıra, ekipmanlarda logo kullanımı, çeşitli reklam alanları kullanımı ile oyuncuların reklam filmlerinde oynaması ve etkinliklere katılımı da yer almaktadır. Basketbol branşında da Ülker markası ile Fenerbahçeyi, Cafe Crown markası ile Galatasaray'1 Cola Turca markası ile de Beşiktaş basketbol takımına sponsor olmuştur (https://www.ulker.com.tr/tr/haberler/haber-detay/spor-sponsorluklari). Ayrica, Ülker tarafindan Fenerbahçe Spor Kulübü basketbol şubesi "Fenerbahçe Ülker" için yaklaşık 14.000 kişilik çok amaçlı spor salonu yaptırlmış ve "Ülker Sports Arena" olarak adlandırlmıştır (https://fenerbahce.org). FIBA 2010 Türkiye şampiyonasının da sponsoru olan Ülker, sponsorluk iletişiminde ağırlıklı olarak sosyal sorumluluk projelerini kullanmaktadır. Türkiye'de taraftar olayları ve şike soruşturmaları nedeniyle futbol alanından çekilen markaların başında gelen Ülker, basketbol branşına desteklerini sürdürürken spora desteğini sporun gelişimi ve çocuklara yönelik yatırımlarla birlikte büyük kulüplerin altyapılarını destekleme ve futbolda saha içi reklamlarla devam etmektedir.

Çocukları ve gençleri hedef alan, gençlerin futbola olan ilgisini arttırarak spor yapmaya teşvik eden, rekabeti dostluk içerisinde ortaya koyarak geleceğin sporcularını yetiştirme amaçlı sosyal projeler kapsamında "Herkes İçin Futbol" projesini TFF ile birlikte hayata geçiren Ülker HİF merkezleri ve Futbol köyleri ile bir çok genç ve çocuğu sporla buluşturmuştur. 2007 yilından itibaren 30 ilde Türkiye'nin dört bir yanından çocukları futbol çatısı altında toplayarak çocuklara spor sevgisini aşılama, spor bilincini geliştirme ve sosyo-kültürel anlamda geliştirme hedeflenmiştir. Ülker ve TFF Futbol Geliştirme Merkezi işbirliği ile hayata geçirilen ve toplam 53 farklı yerde açılan projenin ilki olan Van Futbol Köyü'nde 500 çocuk hem futbol hem de farklı temalarda eğitim almışlardır. 2008 yllında Sinop, Isparta, Bolu ve Sivas'ta gerçekleşen projede kız çocuklarına yönelik de kamp düzenlenmiştir. Futbol köyleri 2009 yllından 2013 ylına kadar 
Malatya, Sakarya, Trabzon, Erzincan, Kütahya, Zonguldak, Sivas, Erzurum, Gümüşhane, Erzurum, İzmir, Nevşehir, İzmir, Balıkesir, vb. şehirlerde çocuklarla buluşmuştur (https://www.ulker.com.tr/tr/haberler/haber-detay/herkes). Sporda farklı projelerde 272 bin çocuğa ulaşan markanın çocuklara yönelik gerçekleştirilen bir diğer iletişim çalışması olan Ülker Mini Minikler Futbol Şenliğ̣i’nde 2007 yllında Ankara'da yaklaşık 39 ilden 1200 minik sporcuya katılım sağlamış, 2008 yllında İstanbul'daki ligde ise 8-10 yaş arasında 4000 çocuğa ulaşılmıştır. 2009 yllında İstanbul'da 4000'e yakın çocuk sağlarken 2010 yllında 20.000; 2011 yilında ise 81 ilde 120.000 çocuğa ulaşılmıştır (http://www.yildizholding.com).

Engelliler için de özel olarak düzenlenen şenliklerde engelli çocukların spor yapmasına olanak tanınmıştır (https://www.ulker.com.tr/tr/haberler/haber-detay/ulkerle-sporda). Yerel turnuvalarda, okul organizasyonlarında belirlenen yetenekli ve henüz lisansı olmayan çocukların eğitim aldığı Futbol Teknik Eğitim Merkezleri de Ülker tarafından amatör ligler, akademi ligleri ve profesyonel takımlara oyuncu yetiştirilmesi amacıyla kurulmuş, fair play, futbol teknikleri ve çevre bilinci gibi eğitimler verilmektedir.

Ülker, 2005 yılında Türkiye Basketbol Federasyonu tarafindan düzenlenen Minikler Basketbol Şenliği’ni desteklemiştir. 2010 yllına kadar yaklaşık 5000 çocuğun faydalandığ1 proje ile FIBA 2010 sponsorluğu bir araya getirilerek Basketbol Minikler Şenliği’ne katılan çocukları maç izlemeye götürmüştür (https://www.ulker.com.tr/tr/toplum-icin). Ülker, FIBA Dünya Şampiyonası sponsorluk etkinliklerinde de FIBA üyesi 110 ülkeden çocukların katıldığ "Children of the World - Dünya Çocukları 2010" projesinin de sponsorluğunu üstlenerek, proje kapsamında 220'si dünyanın dört bir yanından gelen toplam 300 çocuk İstanbul'da ağırlanmıştır (http:/ / www.radikal.com.tr).

Sponsorluk çalışmaları içerisinde basketbol hikâyelerine de yer veren kurum, basketbol tarihi ve şampiyonada yarışan takım ve oyuncuların "mutlu anlarını" ve hikâyelerini bir kitapta derlemiştir. Futbolcu buluşmaları, özel yarışmalar ve ödüller, mutlu anlar temasıyla gerçekleştirilen spor odaklı etkinlikler, eğitimler, spor konulu programlar gibi tüm iletişim kanallarını kullanarak taraftara ve tüketiciye ulaşma gayretinde olan Ülker, özellikle çocuk ve genç kitleye yönelik eğitim ve öğretim konusunda yaptı̆̆1 yatırımlar ile de geleceğin sporcularının yetiştirilmesine zemin hazırlama konusunda destek olmaktadır.

\section{Tartışma, Sonuç ve Öneriler}

Amerika'da 1980'li yıllarda başlayan spor sponsorluğu çalışmaları spor alanına karlı bir ticari ortaklık olarak geri dönüş yaparken, sponsor firmaların da satış arttırıcı faaliyetlerinde çok önemli bir araç olarak kullanılmıştır. Hala Kuzey Amerika'nın en yüksek yatırımı yaptığı spor sponsorluğu global olarak 2019 yllında bir önceki seneye göre \%4 büyüyerek 65 milyar dolar sınırına gelmekte ve 2020-2024 yılları arasında yaklaşı \% \%'lık bir büyüme beklentisi ile 2024 sonunda 89 milyarlık bir sponsorluk hacminin olacağ1 öngörülmektedir. Milyon dolarlık bütçelerden milyar dolarlık bir endüstriye dönüşen spor sponsorluğunda, sponsor firmaların satış, pazarlama ve iletişimsel hedefleri doğrultusunda hem branş hem de sponsorluk tür ve sponsorluk alanlarında faaliyet göstermekte ve bu çerçevede hedef kitle ile etkileşim yaratacak aktivasyonlarda bulunmaktadırlar. Hem sponsor olunan hem de sponsor olan firmaların birbirileriyle olan entegrasyonu, uygunluğu, hedef ve istekleri spor sponsorluğu çalışmasında sponsorlukların yatırım karşıllı̆̆ını ölçebilmek ve uzun vadeli planlar yapabilmek adına büyük önem taşımaktadır.

Türkiye'deki sponsorluk yatırımları yukarıdaki örneklerden de görüldüğü üzere gün geçtikçe yükselmekle birlikte her ne kadar takım sponsorlukları yüksek oranda bir talep görse de bireysel sporculara yönelik olan yatırımlar ile federasyonlara yönelik yapılan sponsorluk harcamaları tercih sıralamasında yukarıya doğru bir ivme kazanmaktadır. Bireysel olarak yapılan sponsorluklar, sporcuların yeterli teçhizatla uygun koşullarda antrenman yapıp daha büyük başarılara imza atmalarına olanak tanırken, federasyonlara yapılan yatırımlar da genel olarak spor sektörünün hem ekonomik hem de eğitim anlamında gelişmesine ön ayak olmaktadır. Böylece spor federasyonları küresel spor pazarında rekabetçi bir konuma gelerek, hem alt yapıdaki oyuncuların yetişmesine olanak tanıyacak yatırımlar yapmakta ve çeşitli organizasyonlar ülke tanıtımına katkıda bulunmakta, hem de farklı spor dallarında eğitimlerin alınmasını sağlayarak sağlıkl, sporun doğasını ögrenen, centilmen oyun kurallarına uyan, olimpik ruha sahip, donanımlı oyuncular yetiştirilmesine imkan sağlamaktadır. Bireysel başarılar ile birlikte takımların başarılan da Türkiye'deki spor sektörüne değer katarak hem tanıtıma hem de ekonomik olarak büyümesine katkıda bulunurken, sponsor yatırımları ile birlikte Türkiye’nin tanıtımı küresel ölçekte geniş kitlelere ulaşmaktadır. 
Spor organizasyonlarının sponsorluğu ise başlı başına ülke ekonomisi ve turizme katkı sağlayarak hem istihdamı arttırmakta hem de organizasyonun gerçekleşeceği kentlerde yeni yapılanmaları beraberinde getirdiği için olumlu olarak katkı sağlamaktadır. Diğer yandan organizasyonlar sayesinde takımların dünya çapında bilinirliği artmakta, bu hem oyuncu hem sponsorluk hem de spor pazarlaması adına federasyon, takım ve sporculara ekonomik ve itibar olarak avantajlı geri dönüş sağlamaktadır. Organizasyonların medya yansıma değeri, tüm ülkelerin basın mensupları tarafindan izlenmesi, dünyanın dört bir yanından gelen tüm sporcuların eş zamanlı olarak aynı çatı altında olup mücadele etmeleri, yine takım taraftarlarının farklı kültürlerden ve ülkelerden bir araya gelmeleri spor endüstrisinin iştahını kabartmakta, sponsorluk yatırımları da bu noktada farklı sektörlerden firmaların yarışa girdiği tüm spor sektörü adına başlı başına en önemli gelir kalemini oluşturmaktadır.

Marka ya da kurum iletişimlerini spor üzerinden konumlandıran kuruluşlar farklı sponsorluk türlerinde faaliyet göstermekle birlikte sporun gelişimine destek olmak adına basketbol ve voleybol liglerinde kendi isimlerini taşıyan takımları ile mücadele etmektedirler. Türkiye'de özellikle Anadolu Efes ve Ülker hem kendi isimleriyle basketbol ve/veya voleybol takımları ile mücadele etmekte eş zamanlı olarak da takım sponsorluğu ve spor odaklı sosyal sorumluluk alanlarında da aktif faaliyet göstermektedirler.

Türk şirketleri spor sponsorluğu alanında ciddi yatırımlar yapmakta, hem sporcu ve sporun gelişimi için faaliyet göstermekte hem de markalarını uluslararası platformlarda konumlandırmak adına dünyanın farklı bölgelerinden spor kulüplerine ve liglerine sponsor olmaktadırlar. Barselona, Manchester United, Avrupa Basketbolu, Rusya Milli Takımı, NBA, vb., dünya sporunda önemli yer teşkil eden spor kulüpleri, oyuncular ve ligler Türk firmaları tarafindan sponsor olarak desteklenmektedir.

Türk Hava Yolları birçok daldaki spor faaliyetlerine destek verip, özellikle Avrupa Basketbol Ligi, FC Barcelona ve Manchester United takımlarının sponsorluğu ile yatırımlarına ciddi bir ivme kazandırırken, 2012 yllına kadar Avrupa Basketbolu'nun sponsoru olan Efes Pilsen ( şimdiki adıyla Anadolu Efes) de özellikle basketbol ve futbol sporlarına yönelik sponsorluk yatıımları ile dikkat çekmektedir. Efes Pilsen, yurt dışındaki gerçekleştirdiği yatırımlar ile de futbol alanında çalışmalarını güçlendirirken, Garanti Bankası'nın spor organizasyonları ve ana sponsorlukları yanında NBA ile gerçekleştirmiş olduğu 2 yıl süren 600 bin dolarlık anlaşma ile basketbola aktardığı kaynak ile sektöre destek vermektedir. Yine 2006 ylından itibaren basketbol alanında ciddi sponsorluk yatırımında bulunan Beko da Türk Basketbol Ligi’ne yapmıs olduğu sponsorlukların yanı sıra uluslararası çapta sponsorluk anlaşmalarına imza atmaktadır. 2009 yılında Türkiye'de düzenlenen Dünya Basketbol Şampiyonası'nın sponsor şirketleri arasında bulunan Beko şirketleri Almanya'nın basketbol ligine de ismini vermiştir.

Burada sözü geçen bir çok marka, sponsorluk çalışmalarını halkla ilişkiler ve pazarlama iletişimi dahilinde stratejik bir iletişim planı içerisinde geniş bütçeler ayırarak gerçekleştirmeye devam ettikçe hem sektördeki rekabeti arttırıp daha iyi ve daha geniş ölçekli yatırımların yapılmasının yolunu açacak, hem de spor iletişimi kapsamında çeşitli aktiviteler yaparak spora ilgiyi arttıracaktır. Ayrıca, var olan taraftarlar ile iletişimi güçlendirmeye destek olacak hem de yatırımların spor alanına stadyum, alt yapı, tesis, transfer gibi alanlara yönelik aktarımı ile birlikte Türkiye'de spor iletişimi ve spor sponsorluğunun gelişimine büyük ölçüde katk1 sağlayacaktır.

\section{Etik Beyan}

"Kurumsal İletişim Cerçevesinde Türkiye'de Paz̧arlama Odakh Spor Sponsorluğu Üzerine Bir Analiz” başliklı çalışmanın yazım sürecinde bilimsel kurallara, etik ve alıntı kurallarına uyulmuş; toplanan veriler üzerinde herhangi bir tahrifat yapılmamış ve bu çalışma herhangi başka bir akademik yayın ortamına değerlendirme için gönderilmemiştir. Bu araştırma doküman incelemesine dayalı olarak yapıldığından etik kurul kararı zorunluluğu bulunmamaktadır.

\section{Kaynakça}

Akyürek, R. (1998). Sponsorluk planlaması. Eskişehir: ESBAV Yayınları.

Argan, M. ve Katırcı, H. (2015). Spor pazarlaması (3. Baskı). Ankara: Nobel Akademik Yayınc1lık.

Bamberry, C. (2005). Marksizm ve spor. Felsefelogos, (1-2), 35.

Baykan, D. (2019). Dünyanı en ünlü binasım THY'nin sponsorluğunda koştular Erişim adresi: https://www.aa.com.tr/tr/dunya/dunyanin-en-unlu-binasini-thynin-sponsorlugunda-kostular/1478442.

Bozkurt, İ. (2005). İletişim odakh pazarlama (2. Bask1). İstanbul: MediaCat.

Bülbül, A. R. (2004). Halkla iliskkiler. Ankara: Nobel Yayınları. 
Büyüköztürk, Ş., Çakmak, E. K., Akgün, Ö. E., Karadeniz, Ş. ve Demirel, F. (2008). Bilimsel araştrrma yöntemleri (2. Baskı). Ankara: Pegem Akademi.

Cevahircioğlu, B. (2007). 'Efes ile ille admm basketbol okullar' projesine katılan 9-15 yas grubu gocuklarn rekreasyon aktivitelerine kathlimlarmmn değerlendirilmesi (Yüksek Lisans Tezi). Selçuk Üniversitesi Sağllk Bilimleri Enstitüsü, Konya.

Cornwell, T. B. (1995). Sponsorship-linked marketing development. Sport Marketing Quarterly, 4(4), 13-24.

Gürel, E. (2006). 12 giant men: As a succesful practice for the sports sponsorship. Dokuz Eylül Üniversitesi Sosyal Bilimler Enstitïsü Dergisi, 8(3), 185-190.

http://brandsandfilms.com/2010/07/louis-vuitton-at-the-world-cup/

http://halklailiskiler.com.tr/Efes_Pilsenden_Milli_Futbol_Tarihimize_Yolculuk.php

http://www.gesf.org.tr

http://www.radikal.com.tr/ekonomi/ulker-fibadan-sonra-dunya-cocuklari-2010-projesine-de-sponsor-oldu1015603/

http://www.yildizholding.com.tr/tr/toplum-icin/kurumsal-sosyal-sorumluluk/spor

https://fenerbahce.org/haberler/arsiv/atasehirde-geri-sayim-suruyor

https://investors.coca-colacompany.com/news-events/press-releases/detail/139/best-player-goal-celebration-atthe-2010-fifa-world-cuptm

https://pazarlamasyon.com/anadolu-efes-euroleague-devotion-pazarlama-gumus-odulunun-sahibi-oldu/

https://sosyalmedya.co/12-dev-adam/

https://www.aa.com.tr/tr/dunya/dunyanin-en-unlu-binasini-thynin-sponsorlugunda-kostular/1478442

https://www.aa.com.tr/tr/sirkethaberleri/ulasim/turkiyenin-bayrak-tasiyicisi-thy-87-yilda-kuresel-marka-haline-

https://www.aa.com.tr/tr/spor/thy-aston-villaya-da-sponsor/220800

https://www.aa.com.tr/tr/spor/turk-telekomdan-sponsorluk-aciklamasi/15898

https://www.aviationbusinessme.com/aviation/2010/jun/14/62586

https://www.bik.gov.tr/turk-spor-tarihine-yon-verecek-proje-2-milyon-500-bin-ogrenciyle-basliyor/

https://www.businesswire.com/news/home

https://www.campaignlive.co.uk/article/louis-vuitton-launches-campaign-pele-maradona-zidane/1000931

https://www.cnnturk.com/2011/spor/basketbol/06/30/efes.pilsenin.yeni.ismi.anadolu.efes/621703.0/index.html

https://www.cumhuriyet.com.tr/haber/thy-euroleaguein-isim-sponsoru-oldu-166020

https://elevent.co/blogs/sponsorship/sponsorship-early-days

https://www.emirates.com/pe/english/destinations_offers/special_offers/fifa_world_cup_packages/our_2010_pac kages.aspx

https://www.fifamuseum.com/en/about/fifa-partners/coca-cola/

https://www.fotomac.com.tr/millitakim/2011/10/07/50-bin-atki-hazir

https://www.garantibbva.com.tr/tr/garanti_hakkinda/kurumsal-iletisim/sponsorluk/spora_destek.page

https://www.hurriyet.com.tr/12-dev-adam-reklam-filminde-12359120

https://www.hurriyet.com.tr/ekonomi/ulker-basketboldan-cekiliyor-16144308

https://www.hurriyet.com.tr/istanbul-park-formula-pisti-nde-15589867

https://www.hurriyet.com.tr/nba-jam-van-istanbul-da-10205641

https://www.hurriyet.com.tr/nba-skills-challenge-istanbulda-basladi-11904771

https://www.hurriyet.com.tr/sporarena/thy-arjantin-devi-river-platee-sponsor-oldu-41155063

https://www.iha.com.tr/haber-thy-bir-deve-daha-sponsor-oldu-109458/

https://www.marketingturkiye.com.tr/haberler/manchester-unitedin-yeni-sponsoru-turk-telekom/

https://www.milliyet.com.tr/skorer/litvanya-da-turkcell-coskusu-1428266

https://www.ntvspor.net/futbol/thy-borussia-dortmund-a-sponsor-oldu-579e33a7c873cc3eb4268fb3

https://shgm.gsb.gov.tr/

https://www.skylife.com/tr/2018-11-business/yildiz-golfculer-turkish-airlines-open-da-yeniden-sahada

https://www.sozcu.com.tr/2020/ekonomi/corona-ile-irtifa-kaybetti-iki-global-sponsorluktan-cekildi-5951157/

https://www.sportspromedia.com/news/turkish_airlines_add_shakhtar_donetsk_to_soccer_portfolio

https://www.statista.com

https://www.Talpa.Org/Wp-Content/Uploads/2012/09/Say1-15.Pdf

https://www.tbf.org.tr/12-dabo/hakkimizda

https://www.tff.org

https://www.turkcell.com.tr/sosyal-destek/gorme-engelli-futbol.html

https://www.turkcell.com.tr/tr/hakkimizda/sosyal-sorumluluk/spor/futbol

https://www.turkishairlines.com/tr-int/basin-odasi/sponsorluklar/

https://www.uefa.com/insideuefa/mediaservices/mediareleases/news/01e1-0f85de6cdade-b8a00943a2e0-1000-castrol-signs-as-official-sponsor-for-uefa-euro-2012tm/

https://www.ulker.com.tr/tr/haberler/haber-detay/herkes-icin-futbol

https://www.ulker.com.tr/tr/haberler/haber-detay/ulkerle-sporda-engel-tanimayanlar-senligi

https://www.ulker.com.tr/tr/toplum-icin/sosyal-sorumluluklarimiz/gecmis-projeler

https://www.yenicaggazetesi.com.tr/50-yila-ozel-logo-9052h.htm

IEG Sponsorship Report (2018). Erişim adresi: http://www.sponsorship.com/IEG/files/f3/f3cfac41-2983-49be8df6-3546345e27de.pdf 
Karadeniz, M. (2009). Pazarlama iletişimi kapsamında sponsorluk faaliyetlerinin önemi. Journal of Naval Science and Engineering, 5(1), 62-75.

Kelvey, S. ve Grady, J. (2008). Sponsorship program protection strategies for special sport events: Are event organizers Outmanevvering ambush marketers?. Journal of Sport Management, 22(5), 550-586.

Kissoudi, P. (2005). Closing the circle: Sponsorship and the Greek Olympic Games from ancient times to the present day. The International Journal of the History of Sport, 22(4), 618-638.

Küçükerdoğan, R , Zeybek, İ. ve Ekï, V. (2011). The global advertising of a local brand in terms of analyzing the visual content: Turkish airlines globally yours advertising campaign. The Turkish Online Journal of Design Art and Communication, 1(1), 42-43. Erişim adresi: https://dergipark.org.tr/tr/pub/tojdac/issue.

Masteralexis , L.P., Barr, C.A. ve Hums, M. (2018). Principles and practice of sport management (6th Edition). Boston.

Meenaghan, T. (1991). The role of sponsorship in the marketing mix. International Journal of Advertising, 10(1), 35-47.

Okay, A. ve Okay, A. (2002). Halkla iliskiler ve medya (2. Bask1). İstanbul: Medicat Yayınları.

Okay, A. ve Okay, A. (2005). Halkla ilişkiler (2. Basım). İstanbul: Der Yayınevi.

Olimpik Hareket (1988). Hürriyet Ofset Matbaacıllk ve Gazetecilik A.Ş., İstanbul.

Öztürk, F. (1998). Toplumsal boyutlaryla spor. Ankara: Bağırgan Yayım Evi.

Peltekoğlu, F. (2005). Halkla ilişkiler nedir?. İstanbul: Beta Yayınları.

Pope, N. (1998). Overview of current sponsorship thought. The Cyber-Journal of Sport Marketing, ISSN: 1327-6816, Volume 2/1, Griffth University.

Sandler, D. M. ve Shani, D. (1993). Sponsorship and the olimpic games: The consumer perspective. Sport Marketing Quarterly, 2(3), 38-43.

Stotlar, D. (1993). Sponsorship and the Olimpic Winter Games. Sport Marketing Quarterly, 2(1), 35-43.

Şentürk, Z. A. ve Selvi, Ö. (2019). Halkla iliskiler ve uygulama alanlar - Yeni eğilimler. Konya: Eğitim Yayınevi.

Turkcell Faaliyet Raporu. (2018). Erişim adresi: www.kap.org.tr/

Türk Telekomunikasyon A.Ş Faaliyet Raporu (2018). Erişim adresi: www.kap.org.tr/

Voigt, D.(1998). Spor sosyolojisi (Çev: A. Atalay) İstanbul: Alkım Yayınları.

Walcott, H. F. (1994). Transforming qualitative data: Description, analysis and interpretation. London: SAGE Publications.

Yetim, A. (2005). Sosyoloji ve spor. Ankara: Morpa Yayınları.

\section{EXTENDED ABSTRACT}

The rapid development and the transformation of sports simultaneously affected and transformed all areas that interact with the sports field. Especially since the late 1960s, the growth of sports-related businesses, companies producing sports goods, mass media, sports fields, stadiums, companies producing sportive commercial products, athletes, professional and amateur leagues within the sports field has not only turned sports into an industry, but has also created sectoral growth within the industry. Nowadays, institutions compete with each other to differentiate, actors in the sports world, which has become a business and profit area and is now seen as a cultural subsystem of modern society with its complex structure, should follow various strategies in order to come to prominence. For this reason, sports have become a favored area for organizations that want to meet with their target audience for communication purposes. Companies are trying to make their names more known through sports by allocating significant amounts of resources to their sponsorships in sports leagues. Sports sponsorship has become an important means used by many companies operating in different sectors around the world in their advertising, promotion and marketing activities. In sports, which is the favored area of organizations that want to reach large masses in a relatively short time with different goals, the sponsor company and the sponsored sports organization providing great advantages to both parties by carrying out a mutually beneficial relationship with the person or group. In such a broad and dynamic area, it is inevitable to use all the possibilities of communication to deliver the desired messages to the target audience. For this reason, it is necessary to manage a correct communication between athletes, sports clubs, commercial companies, suppliers, coaches and all players related to the sports market. In this communication, which will take place within the framework of sports communication, interactions that will add value to both economic and social life are provided by using marketing, public relations, advertising, promotion, sponsorship and similar communication methods. By bringing together the in-kind and cash sponsorship support they provide by attracting the positive image of sports to them, sponsor companies have a different position than their competitors in achieving general corporate or other sponsorship goals such as sales, marketing and media. Sports communications are crucial in terms of increasing awareness and interest in sports products or sports services, encouraging sports consumption and participation, and providing the financial support required for sports programs and facilities. In the communication process, which will take place with the aim of promoting and selling the goods and services of the institution together with the corporate image; reaching wide target audiences, adding value to the corporate image, 
promoting the company, obtain information, and providing access to consumers all products offered by the institution at the highest level are essential objectives while maximizing financial revenue. The fiscal value of sport sponsorship to the sports field is indisputable. Sponsorship support is needed in all steps to be taken in the strategic communication plan within the scope of sports communication, such as the realization of mass sports organizations, the economic power it provides to the teams and the federation, and the implementation of social responsibility projects across the country and even internationally. Sponsorship activities in the sports sector, where materially very high numbers are expressed, are not only the name agreement between the brand and the sports institution or person but also it becomes integrated marketing communication's field of study where the strategic brand communication plans have been implemented, where both brands communicate and interact with each other and mutual image is transferred, brand perception is created and awareness practices are carried out. Besides, in these areas different stories are created around brand communication plans to reach target audiences, and the habitat is prepared conveniently for dialogue, and more than one media is used in an integrated manner. By bringing together the in-kind and cash sponsorship support they provide by attracting the positive image of sports to them, sponsor companies have a different position than their competitors in achieving general corporate or other sponsorship goals such as sales, marketing and media. All investments made contribute positively to the sponsor company, the country, the athlete and the sponsored sports branch, and lay the groundwork for bilateral development. Turkish companies make serious investments in the field of sports sponsorship, operate for the development of athletes and sports, and also sponsor sports clubs, sportsmen, sports leagues and sports organizations in different regions of the world in order to position their brands on international platforms. Also, mobile communication, social media and digital communication are among the most effective channels used in all kinds of sports communication. In this area, the sponsors also construct their communications in these channels and develop sports sponsorship agreements depending on their sector and target audience. Therefore, in this study, a descriptive analysis has been conducted in Turkey, which devotes a significant portion of the companies' sponsorship of sports promotion and marketing budget from various sectors. This study will address the practices of companies operating in different sectors and carrying out sponsorship activities in various sports branches within the scope of sponsors and sports communication and will enable us to see the contribution provided to sports more concretely. 